\title{
電気泳動法，定量的沈降法による組織蛋白質の 酥素活性度，抗原性およで組織抗体の研究*
}

(免疫化学研究 第 4 報)

$\begin{aligned} & \text { 岡山大学医学部 衞生学呚室 } \\ & \text { 緒 } \text { 方 正 名 } \\ & \text { 望 月 } \text { 義 夫 }\end{aligned}$

Studies on Enzymatic Activity Antigenicity of Tissue Protein and Tissue Antibor: by Electrophoresis and Quantitative Precipitin Method.

Masana Ogata, Yoshio Mochizuki

(Department of Hygiene Medical School of Okayama University)

Director Prof. Masuo Ogata

1) The crossreaction of various kinds of tissue proteins against the liver protein antibody has been investigated by a quantitative precipitin method.

(a) The protein fraction of respectively liver, lymphnode, and spleen has been found to crossreact against the antibody in a descending order of reactivity.

(b) Thyroglobulin and lens protein showed no precipitin reaction against the antibody.

2) The protein fraction of liver prepared by successive salting out with sodium sulfate has been investigated by an electrophoretic method.

The $\mathrm{C}_{3}$ fraction $(0-14 \mathrm{~g} / \mathrm{dl})$ shows a simple peak, $\mathrm{C}_{2}$ fraction $(14-28 \mathrm{~g} / \mathrm{dl})$ shows several peaks, while $\mathrm{C}_{1}$ fraction a single peak of obture tapering.

If globulin peaks are respectively named $G_{1}, G_{2}, G_{3}$ in order of mobility, the mobility of $C_{3}$ fraction apparently corrends to $G_{2}$ peak, and that of $C_{2}$ fraction to peaks $G_{1}$ and $G_{3}$, while that of $C_{1}$ fraction to either $\mathrm{G}_{2}$ or $\mathrm{G}_{3}$.

3) The enzyme activity has been measured in respective liver protein fraction, and the $\mathrm{C}_{3}$ fraction was shown to contain catalase and peroxidase, the $\mathrm{C}_{2}$ fraction to contain esterase and cathepsin. The $\mathrm{C}_{1}$ fraction to contain less enzyme than the $\mathrm{C}_{3}$ and $\mathrm{C}_{2}$ fractions.

The precipitate of $\mathrm{C}_{2}$ and anti $\mathrm{C}_{2}$ rabbit serum showed $30 \%$ esterase activity as against the original $\mathrm{C}_{2}$ esterase activity.

4) The anti serum- $\gamma$-globulin antibody has been discovered to crossreact against the protein of respectively lymph node, spleen, and liver in descending order of reactivity, and $\mathrm{C}_{3}, \mathrm{C}_{2}, \mathrm{C}_{1}$ fraction in order of reactivity.

5) The lens protin evidenced two separate major peaks and another small fast-moving one when treated by an electrophoretic method. The faster moving of the two major peaks apparently represented $\alpha$ crystalline while the slower one $\operatorname{did} \beta$ crystalline.

6) The antibody $\mathrm{N}$ produced in various kinds of the tissue protein extracted from the organs of a rabbit that was immunized by means of intravenous injection was discovered to exist in bonemarrow, spleen, lymph node, liver, lung, kidney respectively in order of antibody reactivity.

*指貿 緒 方 㸚 授 
7) The antibody $\mathrm{N}$ produced in the popliteal lymph node in a rabbit immunized by a foot-pad injection was found to be 1.7-2.2 times greater in amount than serum antibody.

The antibody $\mathrm{N}$ remained in lymphatic cells laved with saline, and the antibody $\mathrm{N}$ of lymphatic saline soluble protein was shown to exist in greater amount than that of mitochondria and nucleus fraction by a quantative precipitin method.

8) It is inferred from the above that the liver protein, which the production of the serum albumin has been attributed, contains an extremely small amount of the component which has been ascertained to have the mobility identical with that of serum albumin by an electrophoretic method, and the reticuloendotherial system which has been believed to be responsible for the production of the serum $r$ globulin has a component crossreactive to the serum $r$ globulin, while the tissue antibody increase in the reticuloendothelial system, especially in the lymphatic system through immunization.

\section{緒

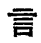

組織蛋白質の性質を調べることは，組織における代謝， 血清蛋白質生成等の動的な研究に対する基本的方法とし て大切な部門である. 一方組織蛋白質の有する性質を研 究する場合, 色々な方法が存在する. 組織の可溶性蛋白 が単一であるか否かということを研究するためには電気 泳動法が最も正確な結果を与える. 又組織蛋白が塩析法 で何種類の分原に分ち得るかを知るためには，溶解度曲 線の解析より研究を進めることが必要である．各分屑に 存在する醭素含有量を研究することは, 醅素精製法の検 討および電気泳動図に扔ける塞の意義付け等に大切な実 験である. 定量的沈降法による免疫化学測定法は各臟器 の相互関係, 特に近似度を測定し度い場合に 1 個の臟器

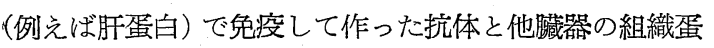
白を抗原とする交叉反応を測定するのに必要でありこれ 飞より各臟器間の綜合的な差異を表わす 1 つの民度とし て研究できる. 組織蛋白分原の交叉反応の研究は, 組織 蛋白の単一か否かの研究の補助手段としても有効であ る. 組織蛋白と血清蛋白の関係を調べるためには, 電気 泳動図の比較と共に，血清 Albumin 拈よび $\gamma$ globulin 抗体と組織蛋白およびその分屑の交叉反応を測定すれ ば, 正確な結果が期待できる. $r$ globulin 生産拉よび抗 体生產の研究を行うためには, 局所および全身免度法に よる各枵蔵中の組織抽出液に含まれた抗体を研究するこ そが適当な方法であろう、以上は細胞中生理的食塩水溶 解性蛋白（主に Cytoplasma protein）を対缘として述へ たが更に核执よび細胞顆粒，またはこれに含有される蛋 白の研究も, 細胞機能や蛋白合成の研究に大切な役割を 果すと思われる.上述の所では組織蛋白として，我々は 肝, 腎, 脾, 淋巴腺等を研究対绫としたが, 水晶体蛋白質 は他の組織蛋白質に比べて電気泳動法では眀確に分離し 得る 2 個の蛋白峯に分離できる点，た免㾤化学的には， 絕対特異性を有する点において特徵を有する故興味ある
研究対象となった。組織蛋白質の研究は Minot Murphy ${ }^{13)}$ 等に上る肝蛋白中の抗惡性幊血因子の研究を始と し, 最近に扮ける E.C. Gjessing2) 等による肝 Cytoplasma protein の Ethanol 分画法に到る迄数多くの研 究が行われ，また，本邦に和いては中村敎授御一派年によ る系統的研究が行われた. 本項発表に当り謹んで敬意を 表する. 本敉室では岡崎8), 岸岡4)の研究がある.

\section{実 驗 方 法}

1) 組織抽出液の調製一一全操作は $5^{\circ} \mathrm{C}$ 以下で行っ た). 牛の肝贜を屠殺後なるべく速に取出し, 水冷生理的 食塩水を用い血管より注射器で洗滌する。この際肝臟 $500 \mathrm{~g}$ に付いて少くとも食塩水 201 位は必要とする. 他 の臓器 (腎, 脾等) るこれに準じて行 5 . 洗湺後の臟器は ミンチで細挫後䟮器重量と等量の生理的食塩水を加えホ モジナイザーで磨碎する．遠心後の抽出液は後述の分画 法の母液とする.

2）醭素活性度測定法一(Catalase) Warburg 検圧 計により Fujita 抢よび Kodama ${ }^{8)}$ の法に従い $0.31 \mathrm{Mol}$ $\mathrm{H}_{2} \mathrm{O}_{2} \quad 0.1 \mathrm{ml}$ より $\mathrm{Nacl}-\mathrm{NaH}_{2} \mathrm{PO}_{4}-\mathrm{Na}_{2} \mathrm{HPO}_{4}-\mathrm{NaHCO}_{3}$ 浮遊夜 ( $\mathrm{pH} 7.7)$ 中で $38^{\circ} \mathrm{C} 30$ 分で発生した酸素量 $\mathrm{cmm}$ を酵素乾燥量 $\mathrm{mg}$ で除して Catalase 係数 $\mathrm{Q}_{02}$ とした.

(Peroxydase)——ピロガロールから $\mathrm{H}_{2} \mathrm{O}_{2}$ と酵素より 生ずるプルプロガリン量を正宗览玉法9) 従いエーテル で抽出し, 重クロム酸加里標準液と比色して計算した。 但し反応液は肝蛋白に括沙る至適条件を考慮に大れて Catalase と同じ緩衝液を用いた. (Esterase)—ethylacetat より Esterase によって生ずる acetate 量を C.J. Harrer and C.G. King ${ }^{10)}$ 法に従い bromthymol blue を指示薬として $0.01 \mathrm{~N} \mathrm{NaOH}$ で滴定した.

(Cathepsin)—-Kunitz ${ }^{11)}$ の法を多少变更して用いた 犬の結晶 Haemoglobin を, 塩酸 Cystein で賦活した 䤉素液を用い, $\mathrm{pH} 4,37^{\circ} \mathrm{C} 20$ 分で水解させ， $10 \%$ 三 塩化酩酸溶液で沈搌させた時残留する $\mathrm{N}$ 量を測定した 
ものである，基質として Hemoglobin を用いない值は 自家融解酵素値とした，両値とも盲験值を差引いた值を 用いた.

3）免疫化学測定法 ${ }^{5,6)}$ 一抗原に用いた牛血清 $\gamma$ globulin は既報局)のごとく脫水艺硝で精製した. 牛血淸 Albumin は Alb.+ $\alpha$ glob. 分屑より既報 6 , 7)の如く馬血 淸の場合と同様に電気泳動法で上昇脚より Albumin を 分離しその純度を再泳動で検定したものである．組織蛋 白抗原の調製法は後述する. 使用抗体は既報の如 $<5,6,7)$ 明攀吸着抗原を Kabat の法で家鬼を免疫して作製し定 量的沈降法は既報 $5,6,7) の$ Heidelberger の法によった。

4) 電気泳動法 $5,6,7)$ — Tiselius 電気泳動裝置によ り $\mathrm{pH} 7.7$ イオン強度 0.2 の燐酸緩衝液中で溫度 $0.5^{\circ} \mathrm{C}$ で泳動した. 成分比, 絕対易動度の測定は電気泳動研究 会規定に従った。

5）塩析曲線の作成法— $40 \mathrm{~g} / \mathrm{d} 1$ 脫水艺硝夜を用い各 濃度の脱水艺硆液の系列を作り肝 C . 分属 1 容に対して 8. 容の各濃度の㧤水艺硝液を加光 $30^{\circ} \mathrm{C} 2$ 時間放置後濾 過し上清 $\mathrm{N}$ を定量しこの值より計算した.

6）水晶体蛋白一一水晶体 1 個に $10 \mathrm{ml}$ の蒸溜水を 加えホモジナイザーで磨碎後, 遠心した上清を用いた。

7) 組織抗体の測定法 (免疫法)一一淋巴腺経由免疫法 は明䙪吸着結晶畉白 Alb. ${ }^{6}$ ) 抗原として皮下免疫を行っ たもので注射量は 1 回量 $4.5 \mathrm{mg}$ である. 全身免疫法の 抗原は酰報6) の方法で調製したyeast 抽出液（但し反応 用抗原としては yeast マンナン), 結晶卵白 Albumin, 牛血清 $\gamma$. globulin を用いた（リンパ液扒よびリンパ

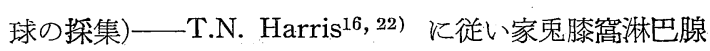
の輸出管を結紮し注射器で探集後遠心する.上清は淋巴 液原液とし, 沈澱は容量の 5 倍の食塩水を pipet で混じ 洗涤後 5 倍量の食塩水を加党, freezing thawing 3 回行い 5 倍稀釈抗体とした. (淋巴組織の探集)——淋巴 液探集後，家鬼を全探血し膝窩巴腺を取り $(\mathrm{ag})$ 細切後 小量の食塩水で振湯洗滌し（重量 $\mathrm{bg}$ ) これに $2 \mathrm{~b} \mathrm{ml} の$ 食塩水を加えホモジナイザーで 2 回抽出した遠心上清を 合せ抽出抗体とした. 食壏水で振湯し取出した液を遠心 した細胞は自由細胞とし freezing thawing を行い, ま た遠心上清は淋巴洗液とした (図 19). (分画遠心法)— Schneider ${ }^{12)}$ の法に従い分画した. 組織ホモジネートを $600 \mathrm{~g}$ の速度で 10 分間遠心した沈澱を $\mathrm{Nw}$ 分屑 (Nucleus. および Unbroken cell) $8500 \mathrm{~g}$ の速度で 10 分遠 心した沈搌を $\mathrm{Mw}$ 分佰 (Mitchondria) として洗滌後, 等 量の食塩水を加光 freezing thawing 3 回行い, 遠心上 清を 2 倍称粎液とした.この液を酸性にして核蛋白を除 去後反応を用いた。遠心の際の溶媒は主に等張庶糖液を 用いた。(副腎皮質ホルモン注射による抗体量測定 $)^{20}$
一一抗結晶畉白 Alb. 家鬼を最終免疫より 3 週放置後皮 下に Adrex $3 \mathrm{ml}$ を注射し直前执よびその後の血清抗体 量を定量的沈降法で測定した。 (組織抗体抽出法)—一免 疫家鬼を全探血後, 全身洗滌を行い更に臟器の個別洗滌 を固有色を呈する迄行う・贜器重量の 2 倍量の食塩水を 加えホモジナイザーで磨碎後遠心し, 更に 2 倍量の食塩 水を加光，ホモジナイザーで磨碎し，両液を加え遠心後 (殆ど $\mathrm{B}$ 分屑には抗体が含まれぬ故) 後述の法で $\mathrm{C}$ 分屋 を調製し含有される抗体量を定量的沈降法で測定した。 各回に扝ける抽出液の蛋白量より推定すれば本法では組 織抗体の約 $90 \%$ 位は抽出されるものと思われる. 贜器 洗滌は可能な限り完全を期して行った.

\section{実 驗 結 果}

I) 䀒臟および藏器抽出液の調製 (A 分屑) 一一生理的 食塩水抽出液を $7000-8000 \mathrm{~g}$ 位で高速遠心した沈澱で あって, Schneider の分画遠心法2)を用いた時は $600 \mathrm{~g}$ 10 分で $\mathrm{Nw}$ 分㞕を，また $8500 \mathrm{~g} て ゙ \mathrm{Mw}$ 分屑を分るこ とができる. (B 分屑) 一 $\mathrm{A}$ 分屑分離後の上清を $10 \%$ 酶酸で $\mathrm{pH} 4.2$ とし沈洪させたものでめる. 本分展には 核蛋白の 1 部が含有される. 但し B 分屑の抽出には分画 抽出法の方が容易である。( $(\mathrm{C}+\mathrm{D}$ 分屑 $)$ - $\mathrm{B}$ 分屑の上 淸を $\mathrm{pH} 7.0$ に中和したるので加熱凝固法, 塩析法, 三塩

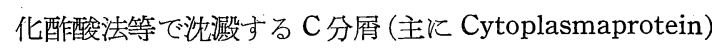
と上淸である D 分屑 (非蛋白性部で ether 等で抽出す る）に分れる．但し沈測方法で C 分佰に属する蛋白は 多少異なる. 以上の A, B, C, D 分雇の名称は Minot 打 よび Murphy13) の分離法に従ったものである.

II） C 分屑の塩析法の研究—-(脫水芒硝分画法) C 分 屑の subfraction を行らために脱水艺硝に対する肝蛋白 扣よび腎, 脾, 淋巴腺蛋白の塩析曲線を研究し, (図 1 a) b) のような結果を得た. 本曲線の解析より C 分屑には, 0-14 g/dl, 14-28 g/dl, 28-38 g/dl の間で 3 つの沈澱部が 存するようであったので，これを $\mathrm{C}_{3}, \mathrm{C}_{2}, \mathrm{C}_{1}$ 分屑として 用いた。他藏器もこれに準じて行った。 (Ethanol 分画 法)- $\mathrm{C}_{3}$ 分展は Ethanol $0.032 \mathrm{Mol}-5^{\circ} \mathrm{C} \mathrm{pH} 5.8$ の 沈搌部であり, $\mathrm{C}_{2}$ 分屑は $\mathrm{C}_{3}$ 沈澱の上清を Ethanol 0.066 $\mathrm{Mol}-8^{\circ} \mathrm{C} \mathrm{pH} 5.8$ で沈搌させたものを用い，また $\mathrm{C}_{1}$ 分 屑は $\mathrm{C}_{2}$ を沈澱させた上清を Ethanol $0.066 \mathrm{Mol}-8^{\circ} \mathrm{C}$ pH $5.8 \mathrm{Zn} 0.02 \mathrm{Mol}$ で沈搌させたものを用いた. 全操作 はアンモニャガス冷東箱中で行った. 以上の方法は抽出 液を分画する法で抽出分画法と名付ける。

III）継続分画抽出法または分画抽出法の研究—一本 法は組織 Homogenateを $28 \mathrm{~g} / \mathrm{d} 1$ 脫水芒硝で抽出し抽出 液を $40 \mathrm{~g} / \mathrm{dl}$ で沈澱させ $\mathrm{C}_{1}$ とし, 抽出後の Homogenate より $14 \mathrm{~g} / \mathrm{d} 1$ で抽出し抽出液を $28 \mathrm{~g} / \mathrm{d} 1$ 以上で沈潵させ $\mathrm{C}_{2}$ とし残りの Homogenateを $\mathrm{pH} 5.7$ で抽出し，14 


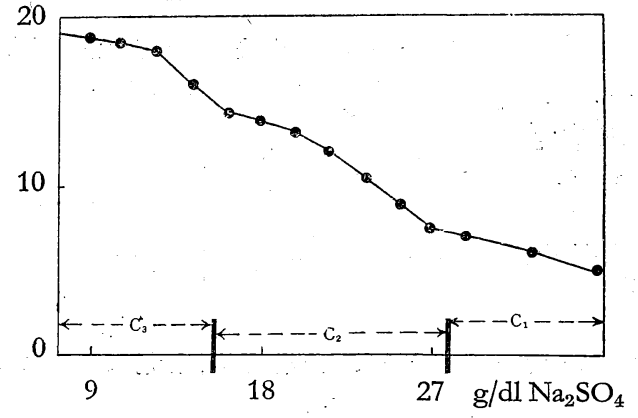

Fig. 1 a) 牛肝 C 分原の脫水世硝に上る塩析曲線

$\mathrm{g} / \mathrm{dl}$ 以上で沈搌させ $\mathrm{C}_{\mathrm{s}}$ とずる. 次いで $\mathrm{pH} 7.0$ で抽出 乙 $\mathrm{pH} 5.0$ または $14 \mathrm{~g} / \mathrm{dl}$ 以上で沈澱させて $\mathrm{B}_{1}$ とし $\mathrm{pH} 7.4$ で抽出したるのを $\mathrm{B}_{2}$ とする. Ethanol の場合

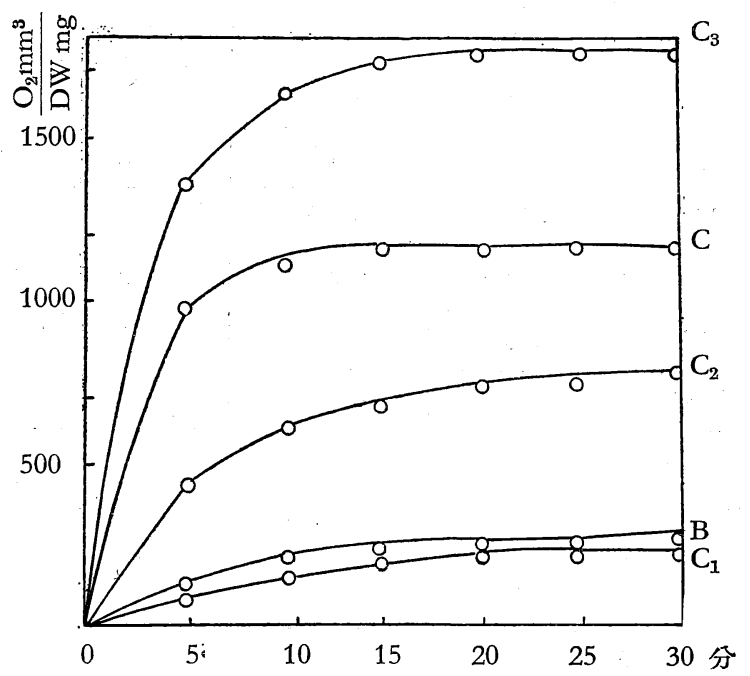

Fig. 2 肝分尿 Catalase 活性曲線

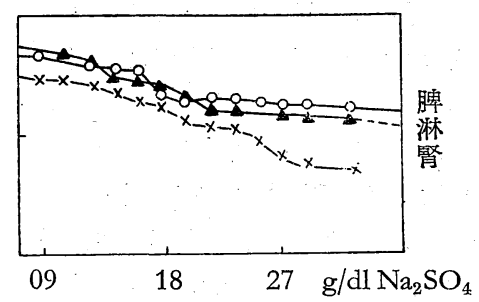

b）各種臟器 $\mathrm{C}$ 分㢏脫水芒硝塩析曲線

は (14) (28) (40) g/dl の代りに (0.032 M pH 5.8) (0.066 $\mathrm{M}$ pH 5.8) (0.066 M+Zn“pH 5.8) を用いる. 本法は自 家融解の多い組織に用いる時特よび B 分屑の抽出には 有利な方法であるが，操作の複雑なのが欠点である. 両法による $\mathrm{C}_{1} \mathrm{C}_{2} \mathrm{C}_{3}$ 分屑は殆えど等しい蛋白であり， また艺水艺硝法による $\mathrm{C}_{3} \mathrm{C}_{2} \mathrm{C}_{1}$ 分屑と Ethanol 法 の $\mathrm{C}_{3} \mathrm{C}_{2} \mathrm{C}_{1}$ 分㞕はほぼ等しい蛋白であるが正確に表 わすには，例えば抽出分画法脱水芒硝 $\mathrm{C}_{1}$ 分展は $\mathrm{C}_{1}$ (ext. frac. $\mathrm{Na}_{2} \mathrm{SO}_{4}$ ) 分画抽出法 Ethanol $\mathrm{C}_{3}$ 分肩は $\mathrm{C}_{3}$ (frac. ext. Ethanol) と記すべきである. 本研究には主 に抽出液分画法による脱水艺硝分屑が用いられ，郎ら $\mathrm{C}_{3}(0-14 \mathrm{~g} / \mathrm{dl}), \mathrm{C}_{2}(14-28 \mathrm{~g} / \mathrm{dl}), \mathrm{C}_{3}(28-38 \mathrm{~g} / \mathrm{dl})$ である.

IV) 各分首酵素活性度の研究一活性度は抽出分 画法に打沙る脫水芒硝分屑を涹析後測定したものであ る. (Catalase)——図 2 は各分屑乾燥重量 $1 \mathrm{mg}$ 当り を発生 $\mathrm{O}_{2}$ 量より測定した值である。 Catalase は $\mathrm{C} の$ Catalase 活性度分首の水溶性蛋白中では, $\mathrm{C}_{3}>\mathrm{C}_{2}>\mathrm{C}_{1}$ の順に存在するが主として $\mathrm{C}_{3}$ 分屑に含有される. 一 方 B 分屑では Catalase 含有量は少小. (Peroxydase)

表 1 肝分屑 Peroxydase 活性度

\begin{tabular}{c|c}
\hline \hline 肝 分 屑 & $\begin{array}{c}\text { Peroxydase } \\
\text { 活性度 } \\
(\mathrm{p} . \mathrm{z} .)\end{array}$ \\
\hline $\mathrm{C}$ & 1.04 \\
\hline $\mathrm{C}_{1}$ & 0.24 \\
\hline $\mathrm{C}_{2}$ & 0.74 \\
\hline $\mathrm{C}_{3}$ & 1.98 \\
\hline $\mathrm{B}$ & 0.26 \\
\hline $\mathrm{C}_{2}$ (水不溶) & 0.11 \\
\hline $\mathrm{C}_{3}$ (水不溶) & 0.18 \\
\hline
\end{tabular}

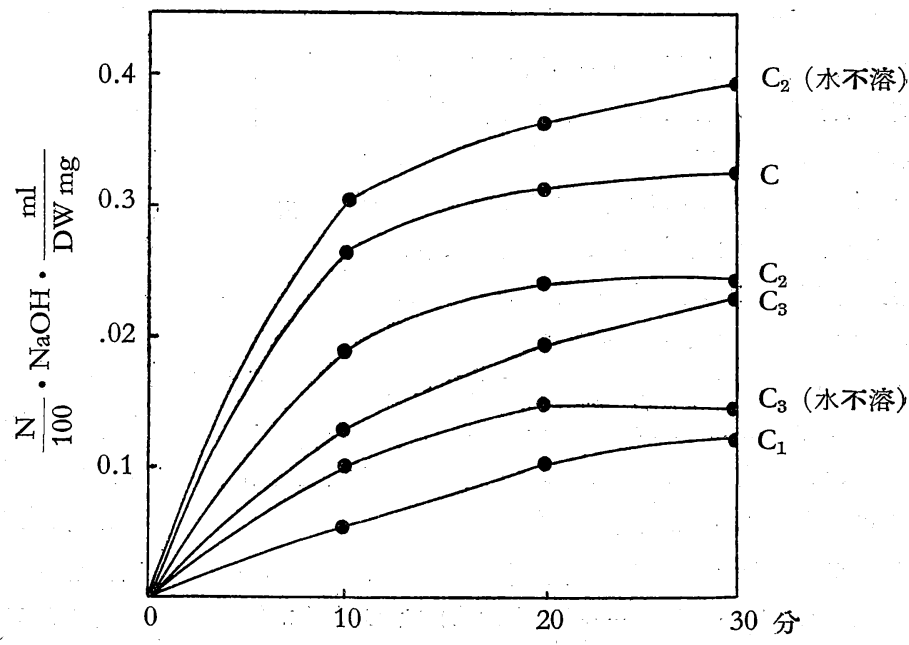

Fig. 3 a) - 肝分屑 Esterase 活性曲線 
一表 1 は各分屑乾燥重量 $1 \mathrm{mg}$ 当りの Peroxydase 活性度を Purpulogalin 生成量9)より測定 した值である. Alkali 性緩衝液中では Peroxydase 含有量は $\mathrm{C}_{3}>\mathrm{C}_{2}>\mathrm{C}_{1}$ の順でありほとん ぞ Catalase 活性度と本行する結果を得た。 Peroxydase は $\mathrm{C}_{3}$ および $\mathrm{C}_{2}$ の水不溶性分展 抢よび B 分屚に和ける含有量は少ない（Esterase)—図 3 は分展 $1 \mathrm{mg}$ 当りの Esterase 活性度を $0.01 \mathrm{~N} \mathrm{NaOH}$ 滴定值で示したもので ある. Esterase は Catalase の場合と異なり， 主に $\mathrm{C}_{2}$ 分㞕に濃縮されて存在するが， $\mathrm{C}_{2}$ の 水不溶性分屑汇最も多〈存在することは興味深 い.また Esterase を含む $\mathrm{C}_{2}$ 分首を抗原とし て抗 $\mathrm{C}_{2}$ 抗体々反応させた場合の沈激中の Esterase activity を測定したのが図 3 b) であり 本例より Esterase の約 $1 / 5$ が沈澱に移行した ことが証明された：(Cathepsin 物よび Autohydrolytic enzym)—表 2 は $1 \mathrm{mg}$ 中の Cathepsin 扔よび Autohydrolytic enzym の 活性度を分解 N より測定した值である.Cathepsin の各分屑に括忷る分布差は上述の酵素 に比して少ないが $\mathrm{C}_{2}>\mathrm{C}_{3}>\mathrm{C}_{1}$ の順に水溶性部 飞含有され, 各分屑の水不溶性沈殿中の含有量 は少ない. Autohydrolytic enzym が B 分展 に多く含有されるごとは注目すべきことであり B 分屑自身に特に消化され易い性質が無いなら ば・B 分㕍に本醭素が多く含有されることにな り従って本分屑を除いた方が肝蛋白としての stability は大であると思われる.C 分屑水溶性 蛋白の活性度を 100 として上述の 5 醭素の分 布を図示したのが図 4 であって， $\mathrm{C}_{3}$ 分佰には Catalase, Peroxydase が, $C_{2}$ 分屑には Esterase が，原 $\mathrm{C}$ 分履より高い活性度で含有さ れることが分る。また $\mathrm{C}_{1}$ 分佰には含有酵素量 は少なく B 分佰には自家融解酵素が多いこと が証明される. Ortinol 法による多糖類合量は $\mathrm{C}_{1} \mathrm{C}_{2} \mathrm{C}_{3}$ では大差無かった。後述のように溶 解度々電気泳動の易動度の関係が眀確でないの で，酵素の位置を決定するのに漸定的に solubility.と mobility の両者で表わす方法, 例光ば Catalase \& 0-14 g/d Na $\mathrm{NO}_{4},-2.4 \times 10^{-5} \mathrm{~cm}^{2}$ Volt ${ }^{-1} \mathrm{sec}^{-1} \mathrm{pH}$ 7.7 Phosphate Buffer という表現を用 万るのが有効ではなからうかと推察する.

V) 各分屑および組織蛋白間の免疫化学的研究 A) 各分屑の交叉后店の研究—図 5 a) b) 抗体汶対する $\mathrm{C}_{1}$ 抢よび $\mathrm{C}_{3}$ 抗原の交文反応を示し, 図

\begin{tabular}{|c|c|c|c|c|}
\hline & $C_{2}$ 分屑 & 反応後 & 反応上淸 & 反庒沈降物 \\
\hline $\begin{array}{l}\frac{\mathrm{N}}{100} \mathrm{NaOH} \text { 滴定值 } \\
\mathrm{ml} . \quad(30 \text { 分 })\end{array}$ & 0.79 & 0.75 & 0.60 & 0.15 \\
\hline $\begin{array}{c}\text { Esterase 活性分布 } \\
(\%)\end{array}$ & 100 & 95.0 & 76.0 & 19.0 \\
\hline
\end{tabular}

Fig. 3 b) 抗肝 $C_{2}$ 分屑家鬼血清対 $C_{2}$ 分原反応時火扱ける Esterase 活性度分布

表 2 肝分屑 Cathepsin 和よび自家融解酵素活性度

\begin{tabular}{c|c|c|c}
\hline \hline 肝 分屑 & $\begin{array}{c}\text { 自家融解酵素 } \\
\text { 活性度 }(\mathrm{a})\end{array}$ & $\begin{array}{c}\text { 総消化 N 量 } \\
(\mathrm{b})\end{array}$ & $\begin{array}{c}\text { Hb K対す而 } \\
\text { Cathepsin 活 } \\
\text { 性度 (b-a) }\end{array}$ \\
\hline $\mathrm{C}$ & 0.06 & 0.57 & 0.51 \\
\hline $\mathrm{C}_{1}$ & 0.05 & 0.43 & 0.38 \\
\hline $\mathrm{C}_{2}$ & 0.11 & 0.83 & 0.72 \\
\hline $\mathrm{C}_{3}$ & 0.10 & 0.69 & 0.59 \\
\hline $\mathrm{B}$ & 0.23 & 0.28 & 0.05 \\
\hline $\mathrm{C}_{2}$ (水不溶) & 0.02 & 0.15 & 0.13 \\
\hline $\mathrm{C}_{3}$ (水不溶) & 0.02 & 0.07 & 0.05 \\
\hline
\end{tabular}

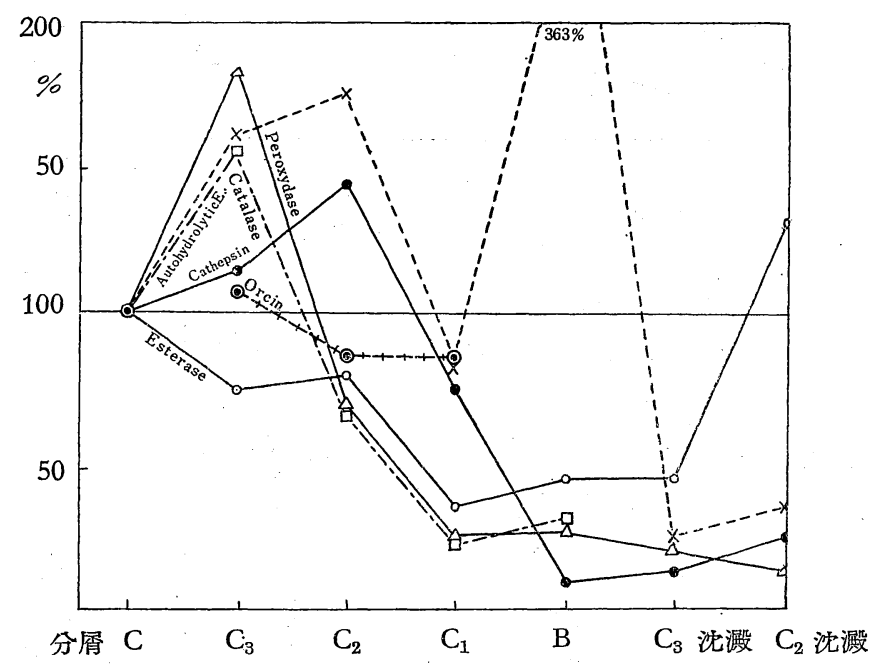

Fig. 4 牛肝分屑各種酵素活性度分布図

6 a) b) 的 $\mathrm{C}_{1}$ 抗体, $\mathrm{C}_{3}$ 抗体を血清 Alb, $\gamma$ glob. の各 々で吸收後 $\mathrm{C}_{1}, \mathrm{C}_{3}$ に存する Alb 抢よび $r$ glob. によ る特異性を隇じて交叉反応を行ったものである. 図 6 a) は $\mathrm{C}_{1}$ 抗体に対する $\mathrm{C}_{1}$ 抗原和よび $\mathrm{C}_{3}$ 抗原の反応でめ り最大沈降量で比較すれば $\mathrm{C}_{1}$ そ100\%とした場合, $\mathrm{C}_{3}$ 


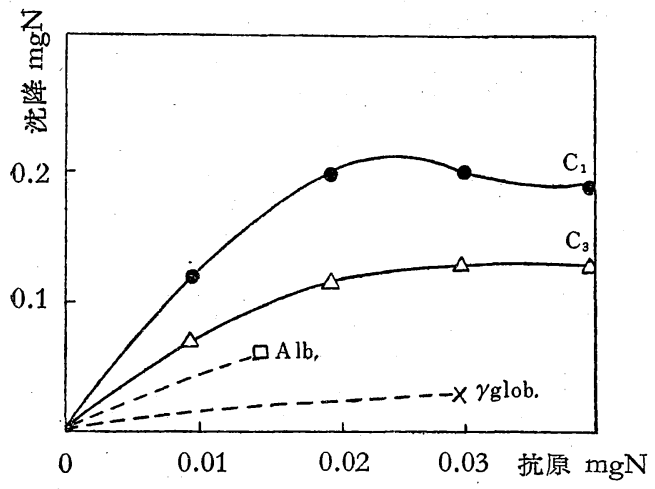

a) 抗 $C_{1}$ 抗体 (Alb., $\gamma$ glob 吸收前)

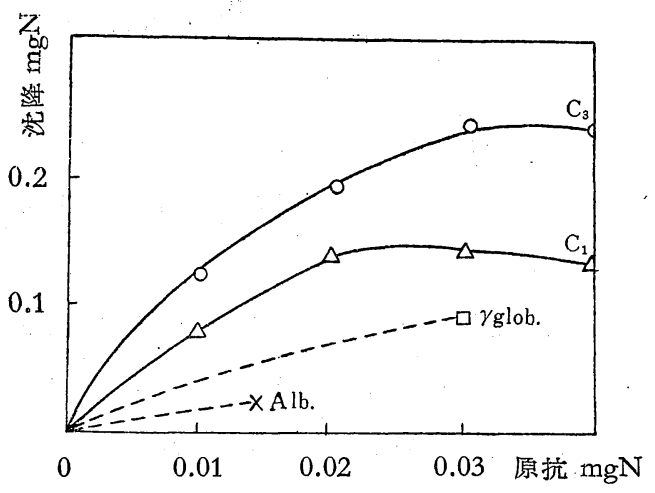

b) 抗 $\mathrm{C}_{3}$ 抗体 (Alb., $r$ glob. 吸收前)

Fig. 5 牛肝蛋白分屑 $\left(\mathrm{C}_{1}, \mathrm{C}_{2}\right)$ 交叉反応定量的沈降図

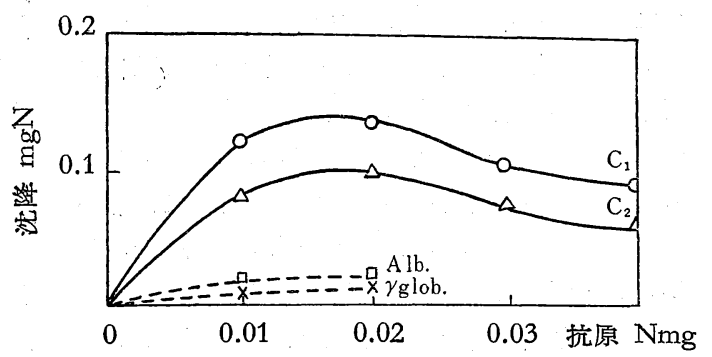

Fig. 6 a) 抗 $C_{1}$ 抗体 (Alb, $r$ glob. 吸收後)

は $74 \%$ であり，b）は $\mathrm{C}_{3}$ 抗体に対する $\mathrm{C}_{3}$ 抗原物よ び $\mathrm{C}_{1}$ 抗原の反応で $\mathrm{C}_{3}$ を $100 \%$ とした場合， $\mathrm{C}_{1}$ は $71.4 \%$ であった．血清 $\gamma$ glob. は 0-14 g/dl であり，血 清 Alb. $\alpha$ glob. は 20-32 g/dl 分画に存するが前報7)の よ5にこの両者の交叉度は約 $10 \%$ しか存しない.これ に比して $\mathrm{C}_{1}$ と $\mathrm{C}_{3}$ の交㕛性が $70 \%$ る存することは後 述のように肝蛋白の電泳図（図 11）が易動度より考えて globulin に相当する峯が主成分でありまた肝蛋白が血淸 蛋白の電泳図に比して単一に近い事と照合せて興味深い ことである.また $\mathrm{C}_{1}$ と $\mathrm{C}_{3}$ の抗原性の差には後述のご

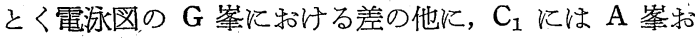
よび B 峯が含まれるが， $\mathrm{C}_{3}$ には含まれぬことも原因と

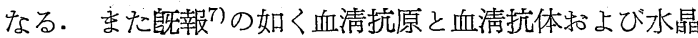
体蛋白とその対応抗体の定量的沈降曲線が double zone または multiple zone の形を示すのに比べて（図 18 參 照) 肝抗体と肝 C 分画の反応が（抗原過剩帶に和ける沈 降量の減少度の少いことを除いては) simple zone に近 い形であること(図 7)よりも肝蛋白の方が単一に近いこ とが明らかと思われる。

B) 各臟器の $\mathbf{C}$ 分屑の交叉反忘に関する研究—図 7 は肝 C 抗体に対する各藏器 C 分㬓を抗原とする定量的 沈降曲線である。肝 C 分局との最大沈降量を $100 \%$ と して各藏器 C 分㢈の最大沈降量で比較した場合に, 腎蛋

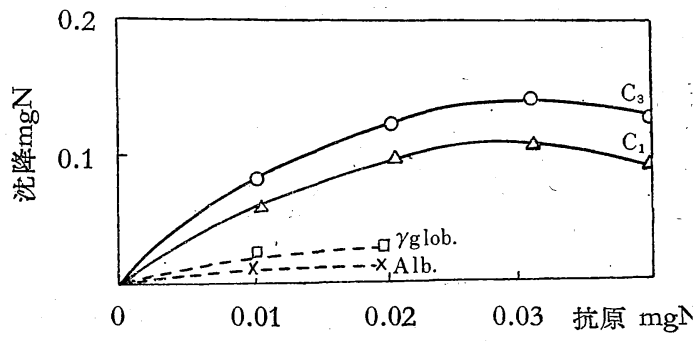

b) 抗 $C_{3}$ 抗体 (Alb, $r$ glob. 吸收後)

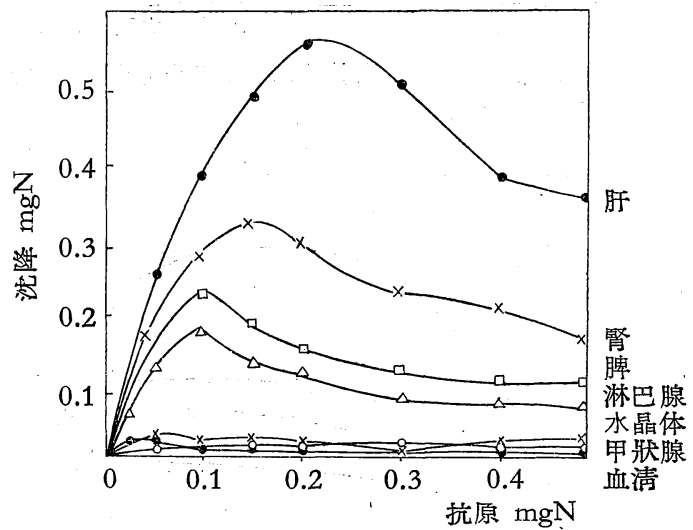

Fig. 7 抗牛肝 C 分屑抗体に対する各臟器 C 分屑交及 反応図

白は $(54.5 \%)$, 淋巴腺 $(38.6 \%)$ ，脾 $(29.8 \%)$ ，でる. 又甲 狀腺 Thyroglob., 水晶体蛋白は殆んど反応性を持たず, この蛋白は絕対特異性(註)を有する特異蛋白といわれた が,血清のみならず,他の組織蛋白との反応性も少い様で ある.以上の結果より肝蛋白との近似性は, 肝>腎>淋 巴腺>脾の順に減少する.また 図 8 は淋巴腺 C 分屃で 免疫した場合に拈ける各臟器 C 分屑の交叉度を表わし， 本図より淋巴腺>脾>腎>肝の順に近似性を有すること 
表 3 牛肝臟蛋白脱水芒硝分零電気泳動測定値

\begin{tabular}{c|c|c|c|c|c|c|c|c|c|c}
\hline & \multicolumn{3}{|c|}{ 成 } & \multicolumn{3}{|c|}{ 分 此 $(\%)$} & \multicolumn{2}{c|}{ 対 } & 易 動 度 \\
\hline 分. 㞕 & $\mathrm{A}$ & $\mathrm{B}$ & $\mathrm{G}_{1}$ & $\mathrm{G}_{2}$ & $\mathrm{G}_{3}$ & $\mathrm{~A}$ & $\mathrm{~B}$ & $\mathrm{G}_{1}$ & $\mathrm{G}_{2}$ & $\mathrm{G}_{3}$ \\
\hline $\mathrm{C}$ & 6.8 & 12.6 & 36.1 & 28.4 & 17.1 & 5.5 & 4.3 & 3.2 & 2.2 & 1.3 \\
\hline $\mathrm{C}_{3}$ & & & 7.6 & 77.1 & 15.2 & & & 3.3 & 2.4 & 1.1 \\
\hline $\mathrm{C}_{3}$ 上清 & 14.8 & 5.7 & 43.2 & 10.2 & 26.1 & 5.4 & 4.2 & 3.5 & 2.8 & 1.4 \\
\hline $\mathrm{C}_{2}$ & 4.4 & 7.0 & 47.8 & 10.4 & 30.4 & 5.4 & 4.7 & 3.3 & & 1.2 \\
\hline $\mathrm{C}_{2}$ 上清 & 13.5 & 13.5 & 24.3 & & 48.7 & 5.6 & 4.7 & 3.6 & & 1.3 \\
\hline $\mathrm{C}_{1}$ & 15.5 & 9.9 & 9.1 & 9.2 & 56.3 & 5.6 & 4.4 & 4.2 & & 1.3 \\
\hline
\end{tabular}

Phosphate Buffer pH 7.7, I.s $=0.2$, 絕対易動度 $=-\mathrm{cm}^{2}$ volt $^{-1} \mathrm{sec}^{-1} \times 10^{5}$

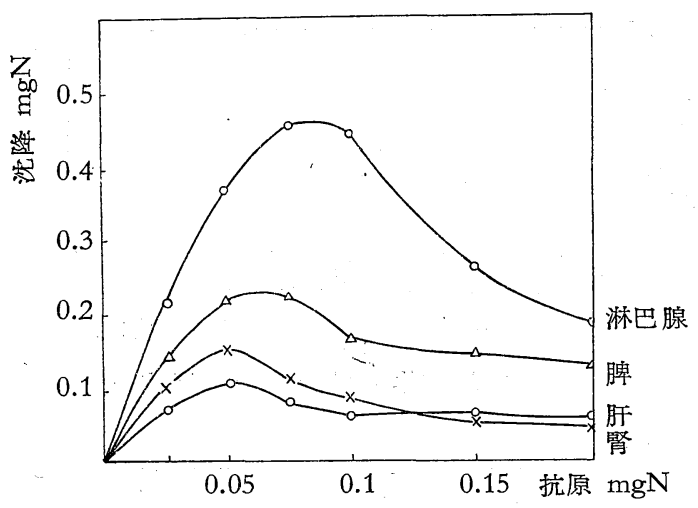

Fig. 8 抗牛淋巴腺 C 分屑抗体に対する各藏器 $\mathrm{C}$ 分㞕 交叉反応図

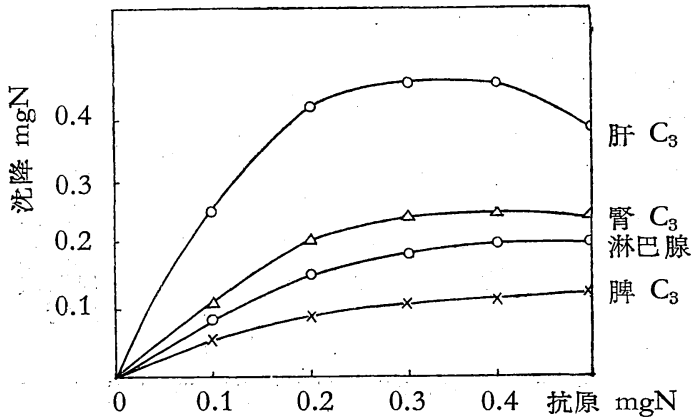

Fig. 9 抗牛肝 $C_{3}$ 分屑抗体に対する各藏器 $C_{3}$ 交叉反 応図

が分り,上記の結果を更に確認する結果となった。図9は 各 $\mathrm{C}_{3}$ 分屑に対する各臟器 $\mathrm{C}_{3}$ 分屑の交叉性を示たしもの で肝蛋白に対する近似性は肝>腎>淋巴腺>脾の順に減 少した. $\mathrm{C}_{3}$ 分屑は各臟器共に 0-14 g/dl の溶解度の部で あり本研究には 2 回精製したものを用いたが溶解度の他 に，電泳図の易動度 子大体近い所飞存する. それ故 Solubility 及易動度の近い蛋白でも含有される贜器が別の場
合には，異る免疫化学的態度を取るということができる。

（註）一般に臟器特異性は同一藏器の各動物における 反応性と共に論ずるもので（例えば牛肝臟と豚肝臓の関 係）あるが我々の研究は臟器相互の関係を論じたもので 厳密な意味の贜器特異性を研究したるのでは無い。

C) 血清 $\gamma$ Glob. および Alb. と各臟器 C および $\mathrm{C}_{1}, \mathrm{C}_{3}$ 分屑の交叉反応の研究——図 10 a) は牛血清 $r$ glob. 家鬼抗体に対する血清拉よび各臟器 $\mathrm{C}$ 分屑抗原の 定量的沈降曲線である. 各臟器の C. 分屑と $r$ glob. 抗 体との反応に批ける最大沈降量は $r$ glob. と抗体の最 大沈降量より低く例えば $\gamma$ glob. $15 \mathrm{mgN}$, 繫 $0.4 \mathrm{mgN}$ 位であるがこれに比して血清の場合は最大沈降量はほぼ 一致し最大沈降帶の抗原量がずれる.このことは血淸に は $r$ glob. と同成分の蛋白が最大沈降帶の比よりかぞえ て約 $1 / 4 \sim 1 / 3$ 近く含まれるのに比し,各組織には $r$ glob. と同一の蛋白ではないが，共通の決定群を持つ蛋白が存 在するとも考穴得る．但しこの場合は臟器蛋白中に抗原 抗体反応阻止因子が無いと仮定した時であり，一方 図 10 a)では組織抗原の沈降曲線は抗原を加えるにつれ， 平行に近くなって扣る故，恐らく実測值以上の抗原を加 えた部に最大沈降帶はないと思われるが最大沈降帶が図 中の抗原量以上の抗原過剩部に存在しないとはいえない ので現在の所明確な結論は避け度い、以上の結果より glob. に交叉性をるつ組織蛋白が $\gamma$ glob. の前階級物で あるか組織固有の glob. が $\gamma$ glob. と共通抗原性を持つ ためかまたは r glob. それ自身であるかは不明であるが。 一方各組織の C 分原の血淸が $r$ glob. に対する親近度 は淋巴腺, 脾, 腎, 肝の順に交叉度が少くなる事実が存す る. 又後述の各臟器の組織抗体含有量子未洗滌淋巴腺, 脾，肝，留の順に少くなる事と考光併せて，上述の結果 は抗体招よび $r$ glob. 生產の盛んな臟器程, 抗体及び $\gamma$ glob. 含有量の高い事を意味し, この問題の解決に興味 


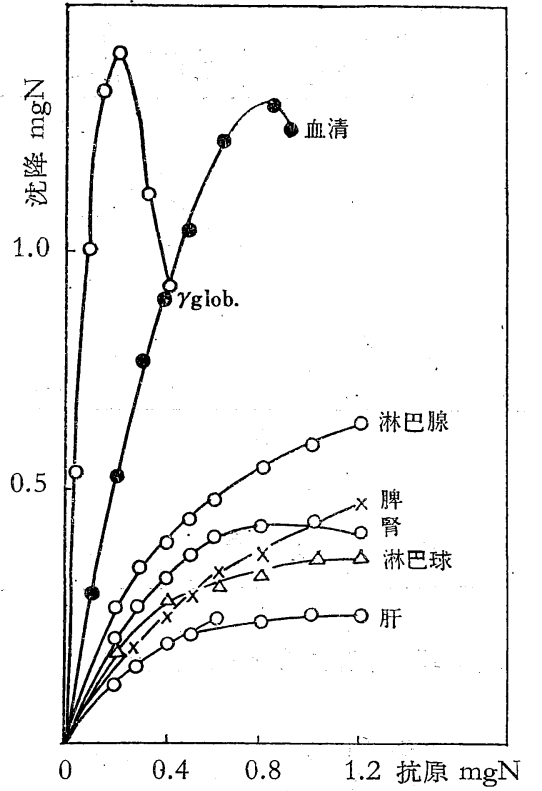

a) 抗牛 $r$ glob. 系

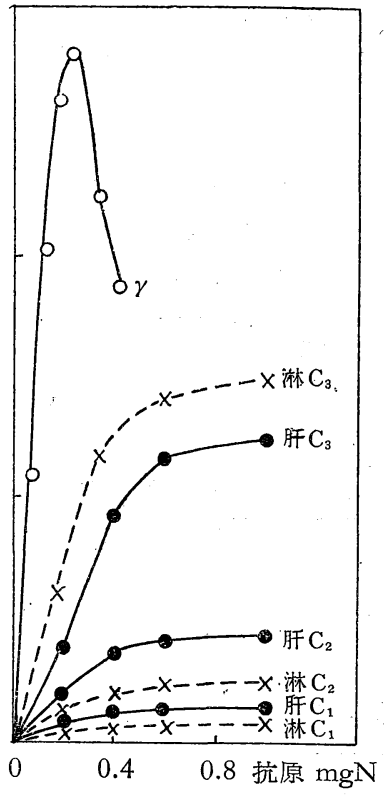

b) 抗牛 $\gamma$ glob. 系

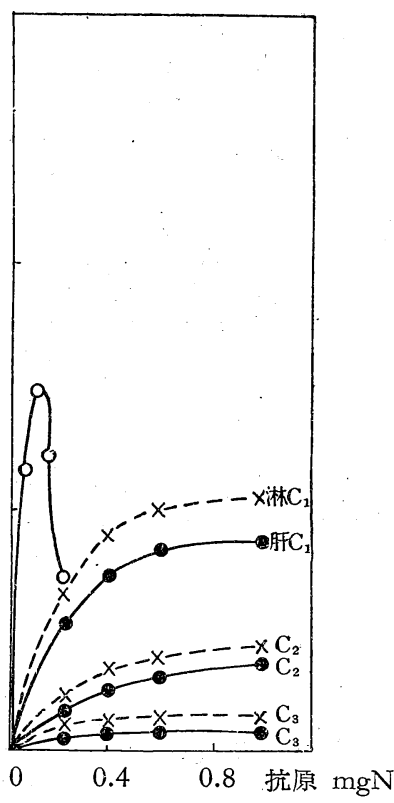

c) 抗牛 Alb. 系

Fig. 10 抗牛 Alb. 和上び $\gamma$ glob. 抗体に対する各臟器和上び各分屑定量的沈降図

深い結果を与える・(但し淋巴腺の位置は洗滌で多少は 变位する) 我々は同一沈降量を生ずるに必要な抗原量の 比よりより計算した值を, 免疫化学的定量值としたが, この値は組織蛋白の場合では最大沈降量が異なる故, $r$ glob. と同一決定群を持つ蛋白に換算することになる. 本計算法では淋巴腺蛋白は $5 \%$ 以上 $r$ glob. 類似蛋白 を含有する. 図 10 b) は $\gamma$ glob. 抗体倿対する肝执よ び淋巴腺の $\mathrm{C}_{1}, \mathrm{C}_{2}, \mathrm{C}_{3}$ 抗原の交叉反応を示し, 実線は 肝, 点線は淋巴腺である. 両臟器共に $r$ glob. 飞対し $\mathrm{C}_{3}>\mathrm{C}_{2}>\mathrm{C}$ の順に交叉度が強く, 殆んど $\mathrm{C}_{3}$ に含まれる とも言い得る.免疫化学的測定值は肝では $\mathrm{C}_{3}$ は $8 \%$ 以 上, $\mathrm{C}_{2} 1.5 \%$ 以上, 淋巴腺では $\mathrm{C}_{3} 14.3 \%$ 以上, $\mathrm{C}_{2} 1.6 \%$ 以上の $\gamma$ 類似蛋白を含むことになる. 以上は, 組織液 に反応阻止因子の無いと仮定した場合の計算值である. 本結果は臟器抗体が $\mathrm{C}_{3}$ 分属に多く含有される結果と本

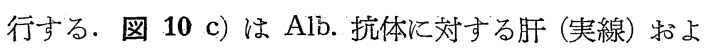
び淋巴腺 (点線) の卒叉反応であり, 両臟器共 Alb. との 交叉応は $\mathrm{C}_{1}>\mathrm{C}_{2}>\mathrm{C}_{3}$ の順で特に $\mathrm{C}_{1}$ には交叉性部の 殆んぞが含まれる. 含有量は淋巴腺 $14.4 \%$ 肝 $8.4 \%$ で ある. $\mathrm{C}_{3}$ は $\gamma$ glob. と $\mathrm{C}_{1}$ は Alb. と交文性があること は $\mathrm{C}_{3}$ と $r$ glob. 括よび $\mathrm{C}_{1}$ と Alb. は脫水艺碙に対する 溶解度が近い故に組織でも血清でも近い溶解度の部は同 じような交㕛性を有することを意味する。 r glob、拈よ び抗体の生產䐟器である淋巴系括よび網內系に $\gamma$ glob. および抗体の多く含有されるのに比べて, Alb. 生產臟器
と云われる肝に，電泳法では Alb. と同じ易動度を有す る搴の含有量が少なく, 肝と他臟器との Alb. 峯の含有 差も少ない末た免疫化学的測定でも肝と他臟器との Alb. 交叉性蛋白の含有量の有意義な差の存しない. 以上 のことより (1) Alb. は肝で生成されるがすぐ血中に放 出される. (2) 他臟器も多少は Alb. 生産関与する等 の要因も Alb. 生產に一応存在するのではないかという ことが推定される.

VI）各分屑の電気泳動法による検討 a) C 分屑の

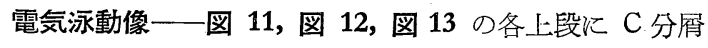
の電泳像を示した．Ｃ分㞕の內易動度の速い峯を $\mathrm{A}$ 峯 とし，また主成分である易動度の遅い Globulin 主峯を

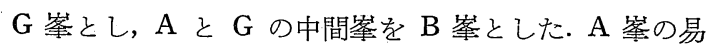
動度は血淸 Albumin 飞近い. B 峷は上昇脚では $B_{1} B_{2}$ $\mathrm{B}_{3}$ の 3 成分に分れる傾向があるが下降脚では明確な分 離は見られず 1 個の本たんな峯の形を示した. G 峯は 上昇脚では明らかに 3 成分より成り, これを $\mathrm{G}_{1} \mathrm{G}_{2} \mathrm{G}_{3}$ としたが，下降脚の場合では，多少分離の不完全な傾问 があった・肝細胞の色素層は赤褐色なたは赤黃色を呈す るが, 電泳図では, 上昇脚で $\mathrm{G}_{2}$ 踤附近より薄い着色が めり $\mathrm{G}_{3}$ 峯附近で明確な着色が見られた. $\mathrm{G}_{2}$ 峯の色素 と $\mathrm{G}_{3}$ 㟯の色素の異同は現在不明である.

b) 脫水芒硝による $\mathrm{C}_{3} \mathrm{C}_{2} \mathrm{C}_{1}$ 分首の電気泳動像— 易動度を中心に考光先ず脫水芒硝分屑を主眼として検討 を行った. $C_{3}$ は $(0-14 \mathrm{~g} / \mathrm{dl}) \mathrm{C}_{2}$ は $(14-28 \mathrm{~g} / \mathrm{de}) \mathrm{C}_{3}$ は 

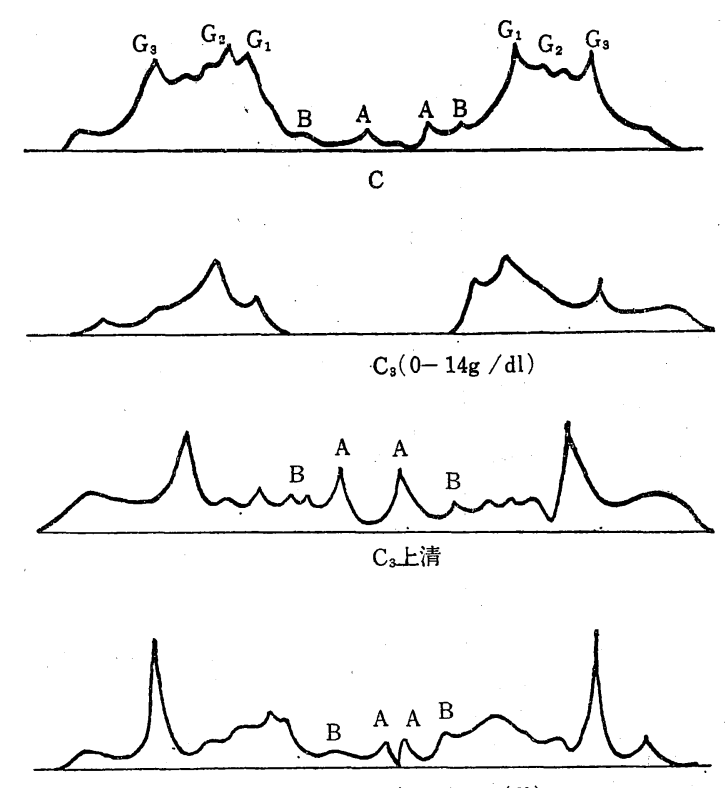

$\mathrm{C}_{2}(14-28 \mathrm{~g} / \mathrm{dl})$
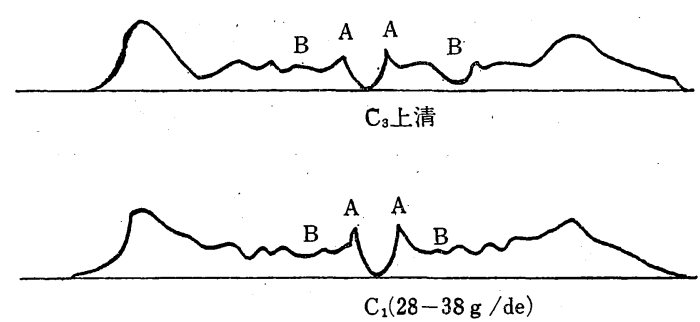

Fig. 11 牛肝蛋白脱水世确分屑電泳図

(註)上より $\mathrm{C}$ 分屑, $\mathrm{C}_{3}$ 分屑, $\mathrm{C}$ 分屑より $\mathrm{C}_{3}$ を沈洪 させた上清, $\mathrm{C}_{2}$ 分俩, $\mathrm{C}_{3}$ 上清より $\mathrm{C}_{2}$ を沈搌させ た上清, $\mathrm{C}_{1}$ 分屑の電泳図である.

(28-38 g/dl) 分屑である㽬(以下図 11 參照).

(1) $\mathrm{A}$ 峯は $\mathrm{C}_{1}$ 分展, $\mathrm{C}_{2}$ 分屑に含まれるが, $\mathrm{C}_{3}$ 分屑に は存在しない. $\mathrm{C}_{1}$ 分展中の $\mathrm{A}$ 峯\%は $15.5 \% \mathrm{C}_{2}$ は $4.4 \%$ 位で $\mathrm{C}_{1}$ に殆えぞ含有される.

(2) $\mathrm{B}$ 峯は $\mathrm{C}_{1}$ 分屑, $\mathrm{C}_{2}$ 分屑に含をれるが, $\mathrm{C}_{3}$ 分屃に は殆えど存在しない， $\mathrm{C}_{1}$ の含有量は $\mathrm{C}_{2}$ より多いが大 差はない.

(3) (1) $\mathrm{C}_{3}$ 分屑の $\mathrm{G}$ 举は単一锋に近い形を示し, 易

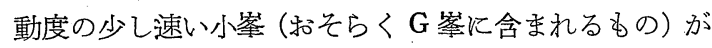
存在する. $\mathrm{C}_{2}$ 分晚の $\mathrm{G}$ 峯は複合峯で主として 2 峯よ り成立する. $\mathrm{C}_{1}$ 分屑は幅の広い単一㱰の形を示す.

（口）各分佰の $\mathrm{G}$ 峯が $\mathrm{G}_{1} \mathrm{G}_{2} \mathrm{G}_{3}$ の何れの峯に属す るかという問題は, $C$ 分屑の $G_{1} G_{2} G_{3}$ 崒の易動度が近 いためと分屑の不安定性のために正確な結論は困難であ った. 現在我々の経験した 1 例を 11 図に示した。本例

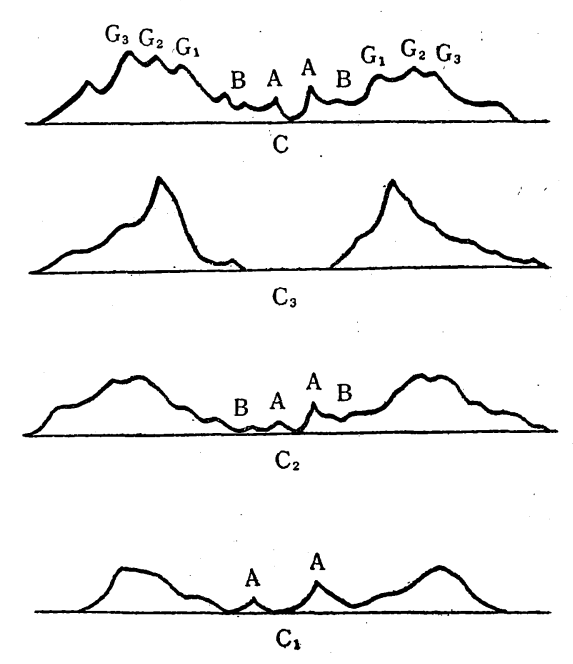

Fig. 12 牛肝蛋白脱水芒磎分屋電泳図
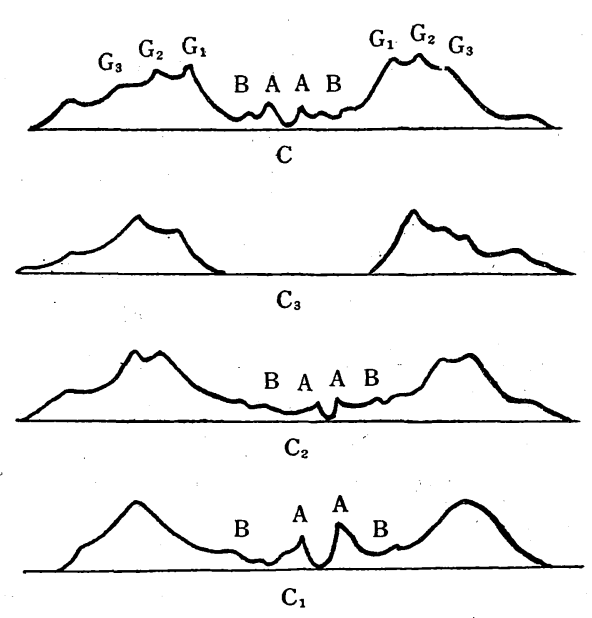

Fig. 13 牛肝蛋白 Ethanol 分屑電泳図

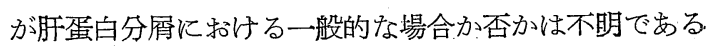
が，沈澱の電泳図と上清の電泳図の正確な比較のできた 例である故に本例を中心に考えることにする．本例では $\mathrm{C}_{3}$ 分屑の主挈の易動度は $\mathrm{G}_{2}$ 附近である. $\mathrm{C}_{2}$ 分屃は $\mathrm{G}_{1}$

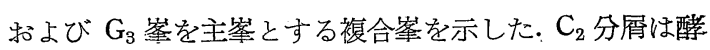
素含有量が多い故, 更に各酵素分布を研究するつるりで ある. $\mathrm{C}_{2}$ 分展の上清の電泳図は $\mathrm{C}_{1}$ 分局に近く, また $\mathrm{C}_{\boldsymbol{t}}$ 分屑は恐らく $\mathrm{G}_{2}-\mathrm{G}_{3}$ 峯附近を中心とする幅広い峯では ないかと推定される.

次いで他の 1 例の各分屑の電泳図を図 12 に示した。 本例では $\mathrm{C}_{2}$ 分屑は複举であるが第 1 例程明確な 2 举 に分離しなかった． $\mathrm{C}_{3}$ 招よび $\mathrm{C}_{1}$ は前例に近かった。第 1 例 (図 11 の例) に㧧ける易動度执よび面積比は表 3 火 示してある故參照され度い:

c) Ethanol 分画法による $\mathrm{C}_{3} \mathrm{C}_{2} \mathrm{C}_{1}$ 分屑の電気泳 
動像— $\mathrm{C}_{3}(0.032 \mathrm{M} \mathrm{pH} 5.8), \mathrm{C}_{2}\left(0.036 \mathrm{M} \mathrm{pH} \mathrm{5.8)} \mathrm{C}_{1}\right.$ $\left(0.066 \mathrm{M} \mathrm{pH} 5.8+Z \mathrm{nn}^{\cdots} 0.02 \mathrm{M}\right)$ で $\mathrm{C}_{3}$ は $\left(-5^{\circ} \mathrm{C}\right), \mathrm{C}_{2}$ 及び $\mathrm{C}_{1}$ は $\left(-8^{\circ} \mathrm{C}\right)$ 附近で分画したものである. A 峯が $\mathrm{C}_{1}$ に 含まれ， $\mathrm{B}$ 峯が $\mathrm{C}_{1}$ 物よび $\mathrm{C}_{2}$ 亿含まれる点, 又 $\mathrm{G}$ 峯が $\mathrm{C}_{3}$ では単一峯に近く, $\mathrm{C}_{2}$ では複合峯であり, $\mathrm{C}_{1}$ では幅 広い単一峯である点では脫水艺硝に括ける $\mathrm{C}_{3} \mathrm{C}_{2} \mathrm{C}_{1}$ 峯 分屑の電泳図に近い. 脱水芒硝の $\mathrm{C}_{3} \mathrm{C}_{2} \mathrm{C}_{1}$ 分屑と Etha$\mathrm{nol}$ の $\mathrm{C}_{3} \mathrm{C}_{2} \mathrm{C}_{1}$ 分屑が厳密に一致するかまたどの点で 差異が存するかは, 將来の研究に待ち度いと思う（図 13 參照).

VII） 電気泳動分睢法による分屑 Cf, Cs と交叉反応 電気泳動図の峯を中心として考えた時の組織蛋白の 特異性を研究するため肝 C分屑を電気泳動後上昇脚上り $\mathrm{G}_{1}$ を目標として分離し，これを faster moving component として Cf とし，下降脚より $\mathrm{G}_{3}$ を目標として 分離し slower moving component Cs とした. 8〜9 回 電泳分離後集めて再泳動した電泳図を図 14 に示した.

Cf 抗体系 (牛血清吸收前)

(a)

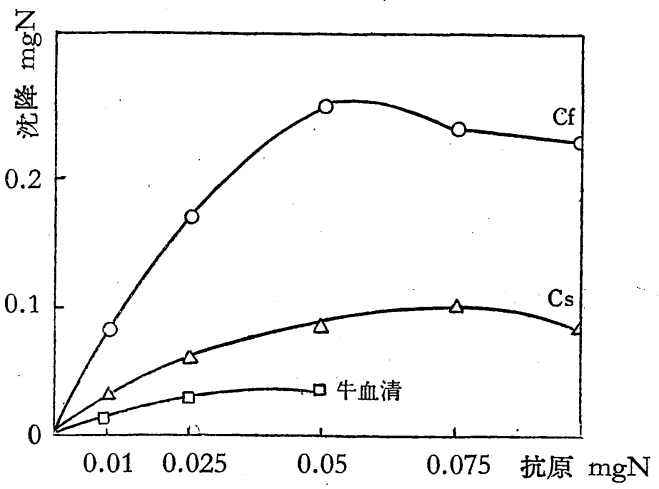

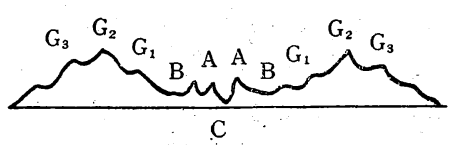
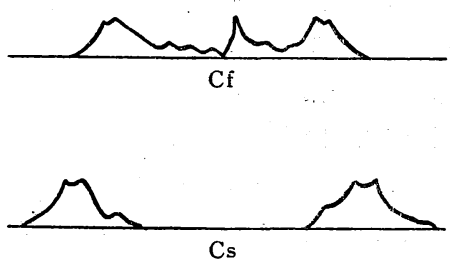

Fig. 14 牛肝 C 分屑電気泳動分離電泳図

Cf $29.8 \%$ であった. この差違は faster および slower moving component の差によるものである. 血淸吸收 後（図 16）交叉度の大なる变動は無かった. Cf, Cs の抗 原性の差が塩析法の $\mathrm{C}_{1} \mathrm{C}_{3}$ の抗原性の差より大である ことより電気泳動の峯の区別の方が溶解度の差より抗原

(b)

Cs 抗体系 (吸收前)

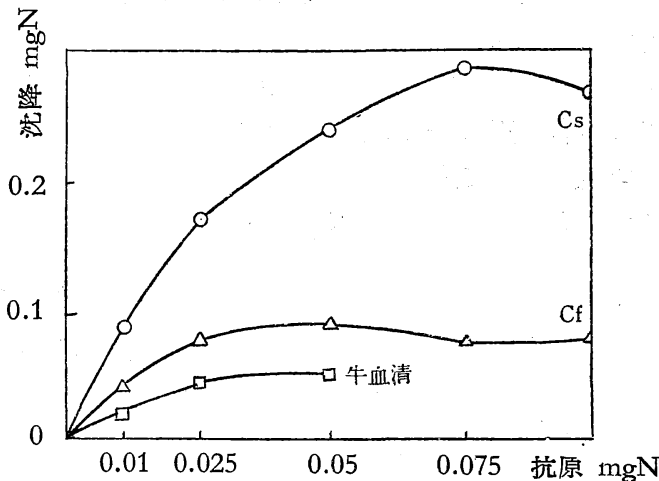

Fig. 15

Cs 抗体系 (吸收後)
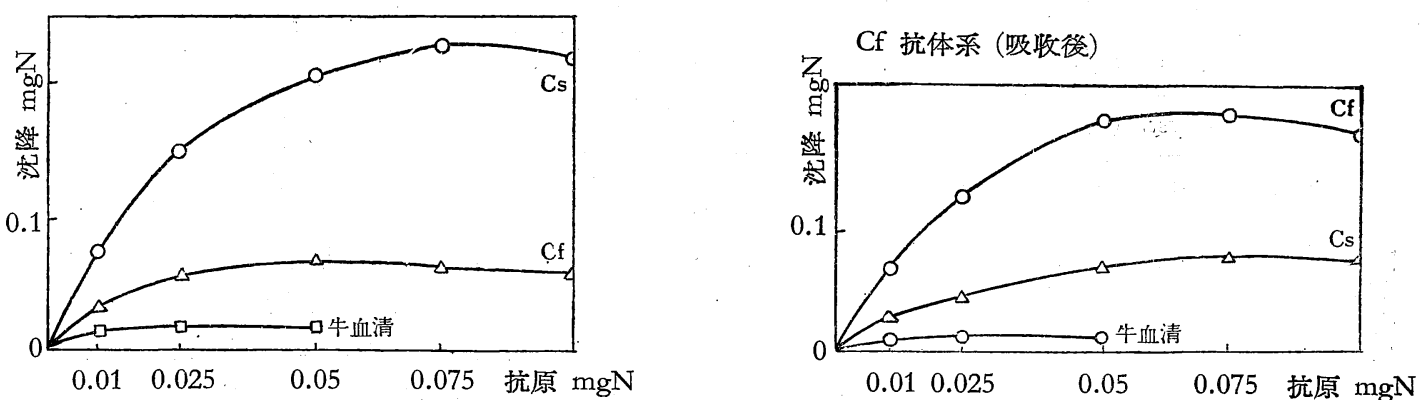

Fig. 16

Cf には $\mathrm{A}, \mathrm{B}, \mathrm{G}_{1}$, および $\mathrm{G}_{2}$ の一部が含まれ，Cs に は $\mathrm{G}_{3}$ 特よび $\left(\mathrm{G}_{2}\right.$ の一部) が含をれる. 次に $\mathrm{Cf}$ 抗原, Cs 抗原小よび各対応抗体を用い, 定量的沈降法で相互の 交叉反応を行い図 15 亿示した。この交叉度は Cf 抗体 に対し Cf $100 \%$, Cs $40 \%$, Cs 抗体に対して Cs 100\%,
性の差が大きいのではないかと思われる。

VIII) 水晶体蛋白犋の研究（以下図 17 和よび表 4 參照)一一牛水晶体蛋白質の分画は, Woods および Burky ${ }^{14,15)}$ の方法を用いた. 水晶体液を $1 / 10$ 規定酶酸 を最強の溷濁を生ずる迄加える. (附加する醀酸量は予備 
実験で予じあ決定し大体 $\mathrm{pH} 4.8 \pm 0.3$ 附近である) その 後水室に一昼夜放置する.沈澱は $\alpha$ Crystalline であり, $1 / 10$ 規定アンモニア液で $\mathrm{pH} 7.4$ の条件で溶解し， 24 時 間透析後, 更に酶酸を $\mathrm{pH} 4.8$ 附近迄加光沈洪させる. 上淸は $\beta$ Crystalline であり, 流水中で透析後, $1 / 10$ 規 定醮酸で残留して扔る $\alpha$. Crystalline を沈搌させる.上 淸は中和後, 脫水肓硝で塩析し濃縮する.

水晶体の電気泳動図 (17 図) は 2 個の明確な㸺を有す るが，この前に小さい fast moving Component が存す る(f 峯と名付られた). $\mathrm{f}$ 峯は血淸 Alb. 飞近い易動度 を有するが， $\alpha$ C Crystalline にも $\mathrm{f}$ 峯が存する場合があ るので本篻の成因は明らかでない, $\alpha$ Crystalline は易動 度の速い峯で第 1 回の等電点沈降法は少量の $\beta$ Crystalline を残すが，第 2 回目の沈降法では $95 \%$ 程度の純 度とすることができた。 $\beta$ Crystalline は易動度の遅い举 で，第 1 回の等電点沈降法で $\alpha$. Crystalline を沈澱させ た後もな和相当部の $\alpha$. Crystalline 峯が残ったが，第 2 回沈降法で $\alpha$ Crystalline を除けば殆んぞ単一な挙とな すことができた.また $\alpha$ Crystalline の後部が丁度血清 の $\alpha$ glob.の上5飞分離する傾向があり，木た $\beta$ Crystalline の部は更に 2 個の峯に分離する傾向が存するが各々 明確な峯として確認することはできなかった，また水晶 体を電泳分離法で上昇脚より易動度の早い㸺を分離し(f
分屃）とし，下降脚より易動度の遅、篻を分離し， $\mathrm{S}$ 分屑 とした. $\mathrm{f}$ 分屑を $\mathrm{pH} 4.8$ とした時に $\mathrm{f}$ 分屑 $1.28 \mathrm{mgN}$ 中 $1.15 \mathrm{mgN}$ 沈澱するので $\mathrm{T}$ 分肩の $88 \%$ が沈澱するこ ととなる。また $\mathrm{S}$ 分屑は $1.13 \mathrm{mgN}$ 中 $0.22 \mathrm{mgN}$ 沈澱
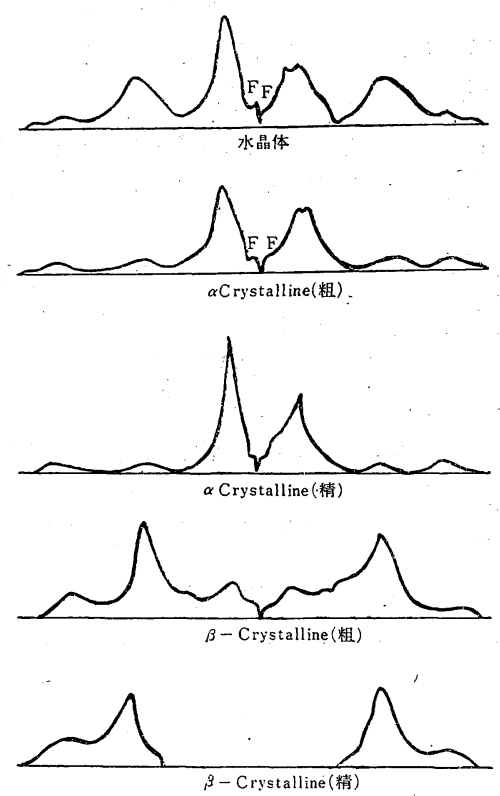

Fig. 17 牛水晶体和よび成分分屑電泳図

表 4 牛水晶体拒よび成分分屑電気泳動測定值

\begin{tabular}{c|c|c|c|c|c|c|c|c}
\hline & \multicolumn{3}{|c|}{ 成 分 比 $(\%)$} & \multicolumn{3}{|c|}{ 絕 対 易 動 度 } \\
\hline & $\mathrm{F}$ & $\alpha$ & & $\beta$ & $\mathrm{F}$ & $\alpha$ & & $\beta$ \\
\hline 水 晶 体 & 1.8 & 50.5 & & 47.3 & 5.4 & 4.6 & & 2.1 \\
\hline$\alpha$ Cryst. (粗) & 1.5 & 88.2 & & 10.3 & 5.4 & 4.5 & & 2.2 \\
\hline$\alpha$ Cryst. (精) & 1.5 & 95.6 & & 2.9 & 5.4 & 4.5 & & 2.3 \\
\hline$\beta$ Cryst. (粗) & 2.3 & 22.7 & 19.7 & 55.3 & 5.5 & 4.8 & 3.7 & 2.3 \\
\hline$\beta$ Cryst. (精) & & & 6.1 & 93.9 & & & 3.6 & 2.1 \\
\hline
\end{tabular}

Phosphate Buffer pH 7.7 I.s. $=0.2,0.5^{\circ} \mathrm{C}$ 絕対易動度 $=-\mathrm{cm}^{2} \mathrm{volt}^{-1} \mathrm{sec}^{-1} \times 10^{5}$

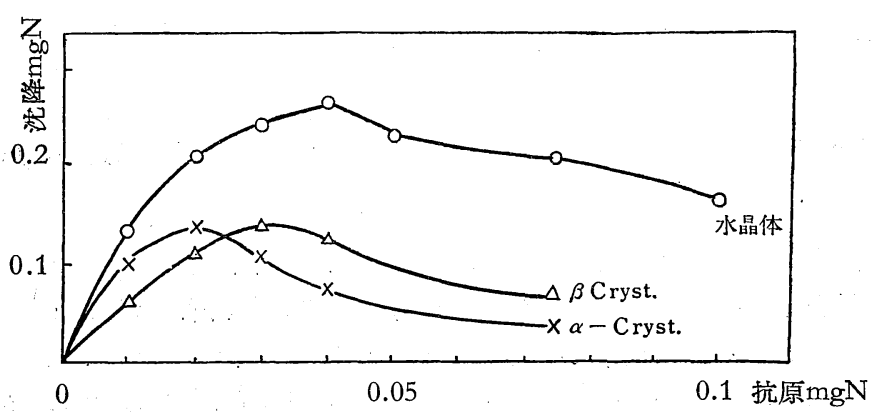

Fig. 18 抗牛水晶体抗体に対する成分分屑定量的沈降図
するので S 分屑中 $19.0 \%$ が沈澱することと なる. それ故 $\mathrm{f}$ 分佰は $\alpha$ Crystalline で $\mathrm{S}$ 分 屑は $\beta$ Crystalline と思われ，一方 $\mathbf{f}$ 分屑と 上昇脚の溷濁の一致することもこの結果と矛 盾しない. 図 18 は水晶体抗体を水晶体抗原

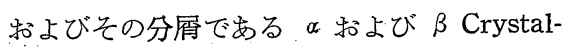
line で反応させた場合の定量的沈降図であっ て, 水晶体抗体との沈降曲線は 2 個の最大沈 降帶を有する所謂複合系 Complexform を形 成し，この成因は相互に独立した抗原性を有 
する $\alpha$ 拈よび, $\beta$ Crystalline より成立することが本図よ り理解される.この結果は水晶体の電泳図が眀確な 2 峯 を有することと対比して興味深い。

IX) 組織抗体の研究（局所 免疫法) 一図 19 a) は足蹠皮下 に 8 回免疫後膝䔰淋巴腺の洗策 後の組織抽出液に打ける抗体量 を, 定量的沈降法で測定した沈 降曲線である.本系統では抗 原抗体稀釈法による Ehrlich, Harris 一派の研究 $16,17,18,19,22)$ がある.淋巴腺抽出液では沈降 $\mathrm{N}$ 量は $0.32 \mathrm{mgN}$ であり,また 洗滌液では $0.25 \mathrm{mgN}$ であっ て, 何れも血清の沈降 $\mathrm{N}$ 量 0.15 $\mathrm{mgN}$ より高い值を示した.こ の際淋巴腺中の淋巴液の沈降 N 量が問題となるが以上の結果よ り局所免疫による組織抽出液の 方が血清より高い抗体 N を有 することとなる。次に図 19 b) は 13 回免疫の場合を測定した もので沈降 $\mathrm{N}$ 量は洗滌淋巴腺 では $0.6 \mathrm{mgN}$ であって a)の $0.32 \mathrm{mgN}$ より多く, 屯た対称 として用いた色疫しない側の淋 巴腺抗体量 $0.15 \mathrm{mgN}$ に比して 3-4 倍の沈降量を示した. 本例

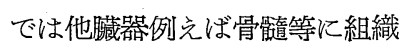
抗体が淋巴腺抗体比比し a) 上 り多く含まれ, 頻回免疫のため 抗原が血清を通り他臓器にも移 行したようである. 淋巴腺抗体 は本例では血清抗体の 1.5 倍の 沈降 $\mathrm{N}$ 值を示した。図 $19 \mathrm{c}$ ) は. (1) 淋巴腺抽出液 C 分屑, (2) 輸出管より採集した淋巴液, (3) 淋巴球抽出液扣よび (4) Schneider 法で分画遠心した $\mathrm{Nw}$ 分㞕, $\mathrm{Mw}$ 分佰の抗体量を定量的沈降 法で測定した沈降曲線である. 本例より淋巴腺抽出液中の抗体 量は輸出管よりの淋巴液より高 いことが分る. 淋巴球抽出液に は淋巴液の約 $1 / 4$ の沈降抗体が 存在した. Hrrris ${ }^{22)}$ は稀釈法:
用い，洗涤前淋巴球の抗体価は淋巴液抗体価より高いが 洗濟後の抗体価は淋巴液より低いことを発表して抢るが 我々の場合は, 定量的沈降法を用いたため抗体量に制限

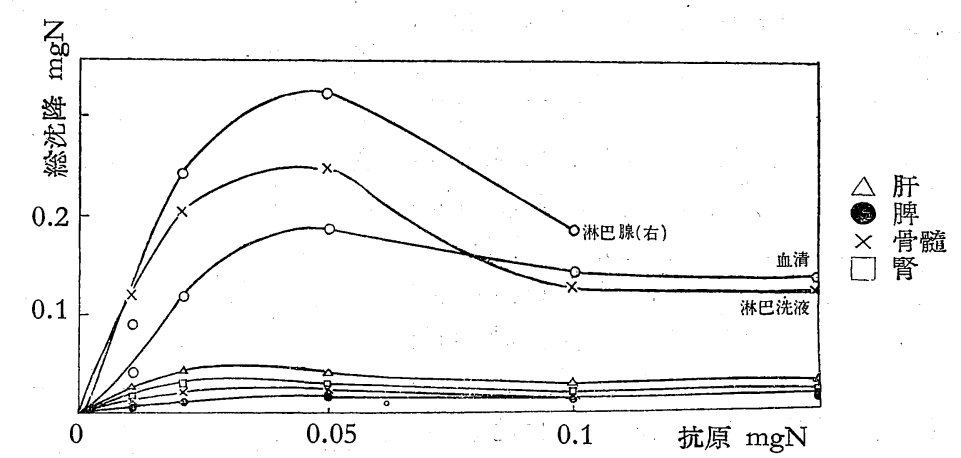

a) 抗卵白 Alb. 家兔抗体 No. 1

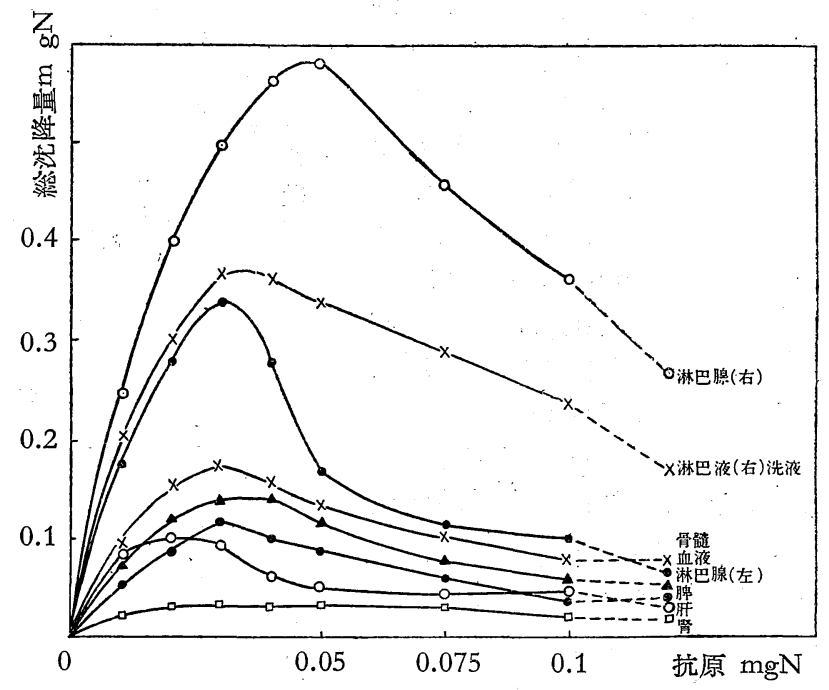

b）抗卵白 Alb. 家鬼抗体 No. 2

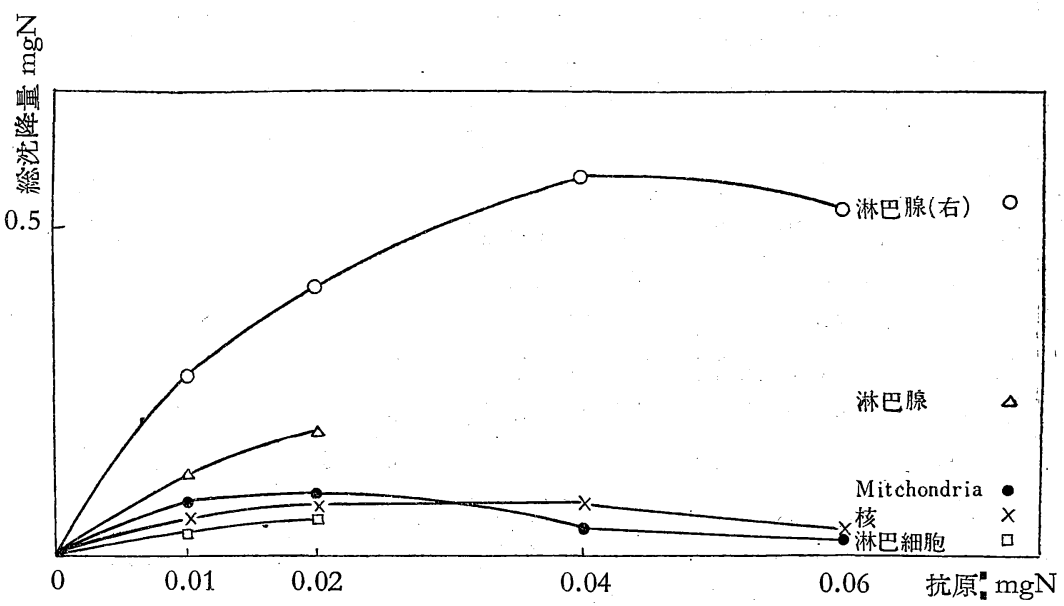

c) 抗卵白 Alb. 家鬼抗体 No. 2

Fig. 19 局所否疫法定量的沈降図 
があったので, 重量の 5 倍量の生理的食塩水洗 滌後の抽出液中の沈降 $\mathrm{N}$ 量であり, 洗涤前淋巴 球との比較は不明である.以上を要言すれば,局 所免疫法によるリン八゚組織抽出液の抗体量は, 輸出淋巴管よりの淋巴液抗体量よりも多く，ま た血清抗体量よりも多い，それ故淋巴腺組織細 胞には，抗体が吸着または含有されて存在する こととなる. 郎ち組織抗体の存在する可能性が あると考光ることができる．洗滌後の淋巴球に も或程度の抗体は存在する.淋巴組織抽出液抗 体の定量的沈降曲線は他臟器々異り, 定型的な 拗物線を画き血清抗体の場合と一致する.この ことは淋巴腺抗体の性質が血清抗体に近くただ ちに mobilizeされ得ること执よび, 抽出液に反 応阻止因子の少いことを示すと思われる. 図 19 c) には淋巴腺組織の $\mathrm{N}$ 和よび $\mathrm{Mw}$ 分展抽出抗 体の畉白 Alb，抗原飞対する定量的沈降曲線が

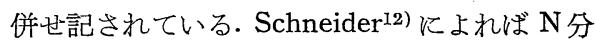
屑は核拉よび未破壇細胞より成り，Mw 分屑は 主に Mitchondria より成るとされているが，こ の 2 分屑より洗滌後 freezing thawing で抽出 した組織抗体量は，溶解性蛋白分屑郎ち C 分屑 に比べて約 $1 / 5$ であって，核や Mitchondria に 含有される抗体量は Cytoplasma protein の 抗体に比べて少ないのではないかと推定される (77 頁註参照) 組織細胞で生成される抗体と血 清抗体との関係を調べる他の 1 つの研究法とし て Dougherty20) 一派で進められた pituitary. adrenotropic hormon の研究がある.

我々は增加した抗体の性質を研究するために mobilizeされれた抗体量を定量的沈降法で測定し た. 図 20 は Adrex 注射後に和ける血清中の沈 降量曲線の変化を示したもので，総沈降量は注 射前は $0.35 \mathrm{mgN}$ であるが注射後 3 時間值 0.37 $\mathrm{mgN}, 6$ 時間值 $0.47 \mathrm{mgN} .9$ 時間值 $0.49 \mathrm{mgN}$ 之增加し, 抗体/抗原比は注射前 10.7, 3 時間値 11.3，6 時間值 14.3, 9 時間值 15.7 と增加した. 抗血清中に抢ける抗体量增加の形式は既報》の 免度経過に和忷る，血清抗体の增加と同形式て あり,抗体增加後の, 沈降曲線る拖物線である故 組織抗体が完成された抗体として血中に放出さ れると見ることができる．このことは淋巴組織 抗体は拋物線であることと対比できる．抗体增 加の原因として (1) 臟器江存在する抗体の放出, 郎ち予備抗体の動員という形式, (2) 抗体生產增 の強形式が考えられるが淋巴球破壞像の見られ

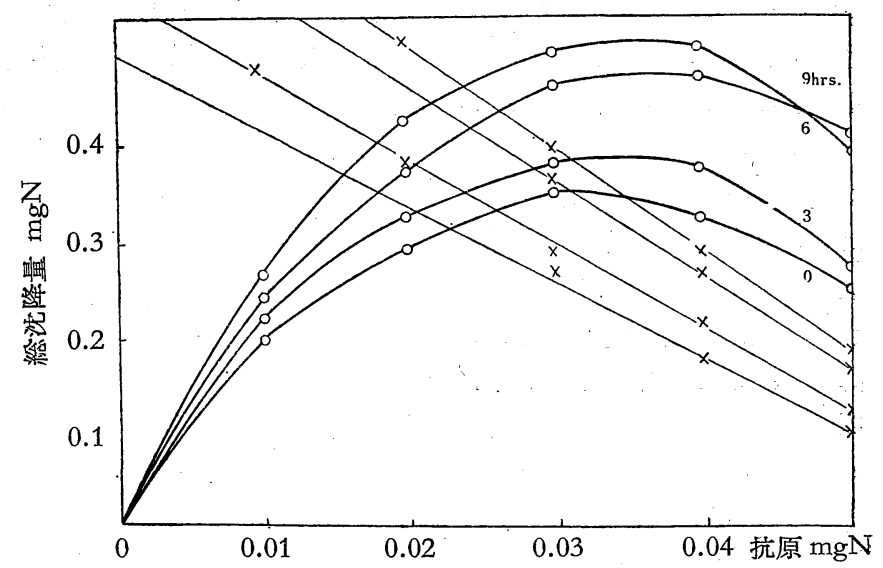

Fig. 20 Adrex 泩射による抗体变動図（抗卵白 Alb. 家鬼抗体）

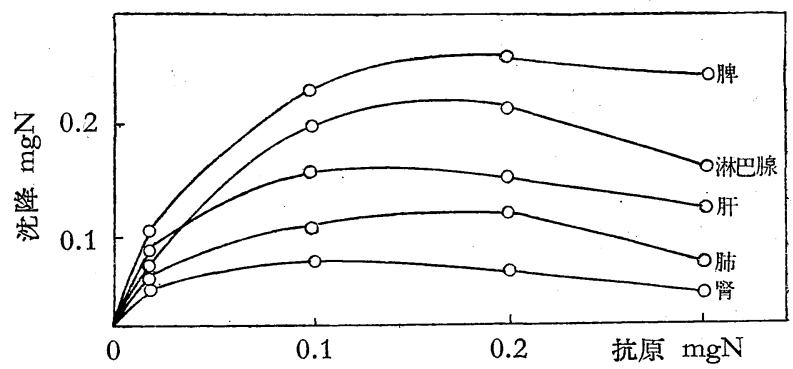

a) 抗酵母マンナン臟器抗体

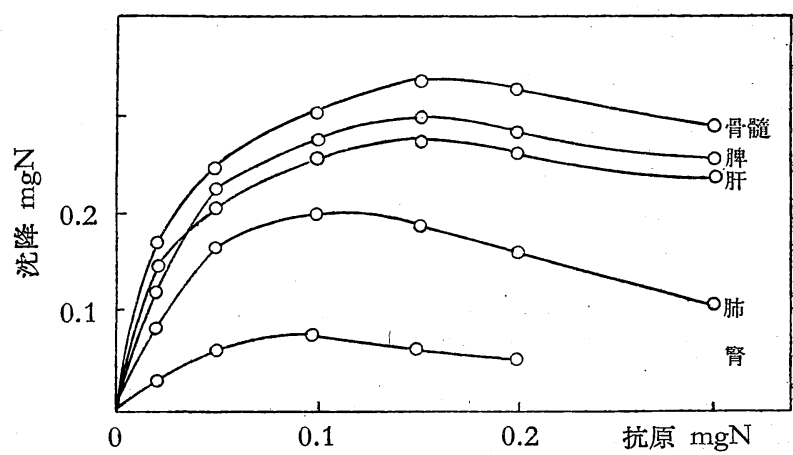

b) 抗卵白 Alb. 臟器抗体

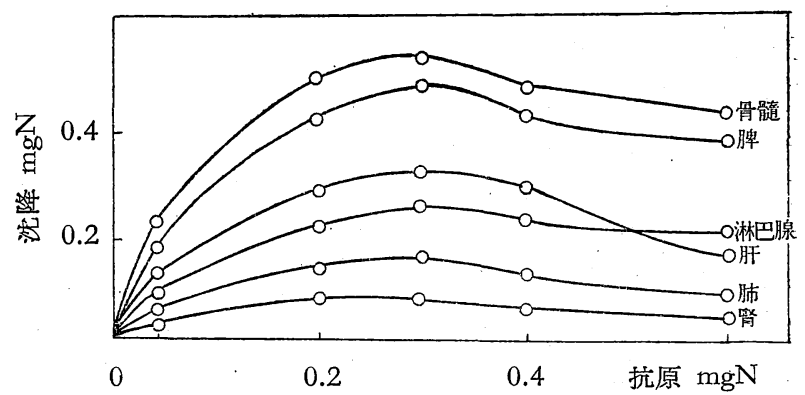

c) 抗牛 $\gamma$ glob. 藏器抗体

Fig. 21 静脈免疫 (全身免疫) 家鬼臟器抗体定量的沈降図 
ること及び增加時間の早いことは，前者に有利な条件と なるが，(1) のみが絕対的条件で (2) が全く存在しないと は明言できない，寧万多少存するのではあるまいか（全 身免疫法)一図 21 は単一抗原で全身免疫を行った場合 飞打仔る各藏器 $1 \mathrm{~g}$ (湿量) 当りの抗体量を定量的沈降法 で測定しだ沈降曲線であって，a）は醳母マンナン，b）は 結晶棴白 Alb：c) は牛血清 $r$ glob. 系の場合である. 本 図より全身免疫法に和计る抗体含有量は骨髓>脾>洗涤 淋巴腺>肝臟>肺>腎臟の順のことが分る. 表 5 は図 21 の結果を表示したもので本例に用いられた抗体は酵母、 ンナン系 $\mathrm{y}=10.5 \mathrm{x}-32 \mathrm{x}^{2}$, 結晶卵白 Alb. I は $\mathrm{y}=20.2 \mathrm{x}$
$-102 x^{2}$, II は $y=16 x-100 x^{2}$ 牛血淸 $r$ glob. 系 I は $\mathrm{y}=13.2 \mathrm{x}-36 \mathrm{x}^{2}$, II は $\mathrm{y}=14.2 \mathrm{x}-40 \mathrm{x}$ の反応方程式を有

して何れも標準抗体であった。醭母マンナンは多糖類で あり $\mathrm{N}$ 含有量が $0.08 \%$ 位であるから沈降 $\mathrm{N}$ 量がそのま ま沈降抗体量となり得る故, 組織抗体測定用には最適の 反応系でめった．蛋白抗原の場合は反応が完全でないよ らであるが一応総沈降量を目標に論ずることとした，そ れ故実際の沈降抗体量注多少少小值となる。 なた肝抗体 でも C 分展は $\mathrm{N}$ 扣よび $\mathrm{M}$ 分屑より多くの抗体を有し た. 表 5 第 II 列は単位臟器湿重量当りの総沈降量で,第 III 列は各臟器含水度の差を考慮して単位乾燥重量当り

表 5 a)

\begin{tabular}{|c|c|c|c|c|c|c|c|c|c|c|}
\hline \multirow[b]{2}{*}{ 臟 } & \multicolumn{4}{|c|}{ 抗酵母マンナン家鬼抗体 } & \multicolumn{3}{|c|}{ 抗卵白アルブミン家鬼抗体 (1) } & \multicolumn{3}{|c|}{ 抗卵白アルブミン家鬼抗体 (2) } \\
\hline & $\frac{\text { 抗体 } \mathrm{mgN}}{\text { 湿臟器 } \mathrm{g}}$ & $\frac{\text { 抗体 } \mathrm{mgN}}{\text { 乾臟器 } \mathrm{g}}$ & $\begin{array}{c}\text { 総抗体量 } \\
\mathrm{mgN}\end{array}$ & $\begin{array}{c}\text { 血清比 } \\
(\%)\end{array}$ & $\frac{\text { 抗体 } \mathrm{mgN}}{\text { 湿臟器 } \mathrm{g}}$ & $\frac{\text { 抗体 } \mathrm{mgN}}{\text { 乾臟器 } \mathrm{g}}$ & $\begin{array}{c}\text { 総抾体量 } \\
\mathrm{mgN}\end{array}$ & $\frac{\text { 抗体 } \mathrm{mgN}}{\text { 湿臟器 } \mathrm{g}}$ & $\frac{\text { 抗体 } \mathrm{mgN}}{\text { 乾臟器 } \mathrm{g}}$ & $\begin{array}{c}\text { 經抗体量 } \\
\text { mgN }\end{array}$ \\
\hline 血 淸 & 0.97 & & & & 1.08 & & & 0.74 & & \\
\hline 骨具髓 & & & & & 0.33 & 3.50 & & 0.20 & 2.10 & \\
\hline 脾 & 0.26 & 2.70 & 0.65 & 26.8 & 0.30 & 3.48 & 0.90 & 0.19 & 1.98 & 0.57 \\
\hline 淋 巴 腺 & 0.22 & 2.34 & & & 0.27 & 2.86 & & 0.23 & 2.45 & \\
\hline 肺 & 0.16 & 1.58 & 9.80 & 16.5 & 0.28 & 2.76 & 18.2 & 0.15 & 1.48 & 7.20 \\
\hline 肺 & 0.12 & 1.37 & 3.00 & 12.4 & 0.21 & 2.39 & 4.60 & 0.13 & 1.48 & 3.12 \\
\hline 腎 & 0.11 & 1.02 & 2.65 & 11.3 & 0.07 & 0.63 & 1.68 & 0.05 & 0.47 & 0.90 \\
\hline 淋巴洗液 & & & & & 0.10 & & & 0.06 & & \\
\hline 淋巴細胞 & & & & & 0.02 & & & 0.02 & & \\
\hline
\end{tabular}

b)

\begin{tabular}{|c|c|c|c|c|c|c|}
\hline & \multicolumn{3}{|c|}{ 抗牛血清 $\gamma$ グロブリン家鬼抗体（1） } & \multicolumn{3}{|c|}{ 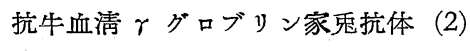 } \\
\hline 臟器 & $\begin{array}{c}\text { 抗体 mgN } \\
\text { 湿臟器 } \mathrm{g}\end{array}$ & $\frac{\text { 抗体 } \mathrm{mgN}}{\text { 乾臟器 } \mathrm{g}}$ & $\begin{array}{c}\text { 総抗体量 } \\
\text { mgN }\end{array}$ & $\frac{\text { 抗体 } \mathrm{mgN}}{\text { 湿臟器 } \mathrm{g}}$ & $\frac{\text { 抗体 } \mathrm{mgN}}{\text { 乾臟器 } \mathrm{g}}$ & $\begin{array}{c}\text { 総抗体量 } \\
\mathrm{mgN}\end{array}$ \\
\hline 血＼cjkstart淸 & 1.44 & & & 1.54 & & \\
\hline 骨＼cjkstart髓 & 0.56 & 5.88 & & 0.56 & 5.88 & \\
\hline 脾 & 0.52 & 5.41 & 1.56 & 0.46 & 4.78 & 1.61 \\
\hline 淋 巴 腺 & 0.28 & 2.97 & & 0.32 & 3.38 & \\
\hline 肝 & 0.33 & 3.25 & 23.2 & 0.28 & 2.76 & 18.8 \\
\hline 肺 & 0.16 & 1.82 & 3.20 & 0.12 & 1.37 & 2.45 \\
\hline 筲 & 0.06 & 0.56 & 1.62 & 0.08 & 0.74 & 2.00 \\
\hline 淋巴洗液 & 0.12 & & & 0.10 & & \\
\hline 淋巴細胞 & 0.03 & $\ldots$ & & 0.12 & & \\
\hline
\end{tabular}


の総沈降量として表わした值である. 第IV 列は臟器に含 有される総抗体量を表わし，この結果のみから云えば, 肝 のような重量の多い贜器は案外抗体生產の関与度は高い かるしれない. 第 $\mathrm{V}$ 列は血清 $1 \mathrm{ml}$ 中の沈降 $\mathrm{N}$ 量と組織 湿重量 $1 \mathrm{~g}$ 中の沈降 $\mathrm{N}$ 量の比を求めたものである. 以 上の結果より単位重量当りの抗体量は骨髓脾洗滌淋巴腺 旰肺腎の順に少いことが分る. 但し未洗㴪淋巴腺は骨髓 と殆んで等しいかまたは多い，一般に網內系贜器の前三 者と朋とに多少の差があり肝と肺腎との差は大きい。強 力に洗滌後の $r$ glob. 系の例では腎に殆んど抗体は含有 されなかった. 単位重量当りの比較は臟器中の抗体純度 の比較であり, 郎ち抗体生產組織含有率の比較であるが, 総量の時は前述のごとく肝等が問題となる. 定量的沈降 曲線より云光ば臟器抗体の当量帶に和ける抗体/抗原比 は血清抗体上り低く, 且つ淋巴腺抗体以外は批物線に対 し多少偏位する. また臟器 $1 \mathrm{~g}$ 当りの最大沈降帶は血清 より抗原過剩側江存する.以上の事実は組織抗体の場合, 反応の不完全性を示するので, その原因は, 抗体自身の 不完全なためか抗体量の少いために沈降物の溶解度によ るものか，または組織蛋白に反応阻止因子の存するため かの何れかと思われる. 組織抗体の存する分屑はrglob. と反応交叉性の部が $\mathrm{C}_{3}$ に殆んど存すること拉よび, 既報 のごとく組織抗体が Felton の solution で濃縮されるこ とより, 恐らく $\mathrm{C}_{3}$ 分屑に存すると思われる. また組織㧤 体の贜器含有量の順序は組織培養に括ける抗体生產の順 序と矛盾しない. 一方全身免疫法の時は組織洗滌後の血 淸抗体の残留が誤差となる。本研究は局所免疫法による 淋巴腺抗体の研究が他の網內系臟器拉よび淋巴組織含有 臟器に応用できる可能性を全身免疫法を用い検傠したも のである. Harris $\left.{ }^{19}\right)$ は淋巴腺のみならず脾のマルピギー 氏小体の activity と抗体価の本行することより本組織が 抗体生產に与ることを推定し, また Moeschlin の行っ た脾に免疫時 plasma 細胞の出現を見出した実験 ${ }^{21)}$ と考 元併せ，我々の実駼結果も淋巴球說のみを中心考光た 場合でも成立する可能性が存するが，一方抗体生茛に網 內系細胞の関与も否定できない，それ故抗体生產に関与 する細胞が淋巴系のみか，また網內系に属する他の細胞 群が関与するかは今後の研究侍ち度いと思う.

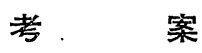

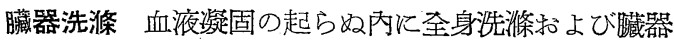
洗滌を行う必要があるが，一方かかる洗滌法を如何に完 全にしても贜器より残留血清の全部を取り去ることは不 可能であるから, 血清蛋白々臟器蛋白の比較としての交 叉度和よび贜器抗体の含有量の研究の時には, 結論を憤 重にする必要がある。贜器抗体が細胞に吸着性であるか,
含有性であるかを決定するのは今後の問題である、電泳 図藏器分㞕の電泳図に就いても glob. の易動度を有する 峯が主峯であるが, これらの峯に Protein-protein association が有るか否かは, 峯の意義付けに大切で, 酵素含 有分佰と, 結晶化酵素の易動度の比較も, Protein-protein association の解決に大切である. 易動度の決定には, 脫 水芒硝分屑が基本的には簡易であるが，䤏素分画自身之 しては塩析剤除去の容易な Ethanol 法が有效と思われ る.

\section{結論}

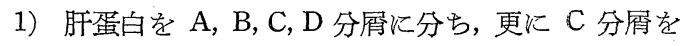
脫水艺硝の溶解度曲線より $\mathrm{C}_{1}, \mathrm{C}_{2}, \mathrm{C}_{3}$ の三分原分つこ とができた．2）各分佰の酵素分布を調べ $\mathrm{C}_{3}$ には Catalase, Peroxydase, $C_{2}$ には Esterace が多く, C $C_{1}$ は䤏 素含有量が少く，B には自家融解酵素が多い結果を得た。 3) $\mathrm{C}_{1}$ 分展々 $\mathrm{C}_{3}$ 分屑は相当の艾叉反応が存し, また肝 C 蛋白系沈降曲線が単一に近いことは, C 分扈の電泳図 飞 G (glob.) 分屑が多いことと同じく, C 分屑が血清等 より単一に近いことを示す結果を得た. 4) 肝 C 抗体, 淋巴 $\mathrm{C}$ 抗体に対する各䟮器の交叉反応上り, 肝, 腎, 淋 巴腺, 脾の順に近似性が存し, また溶解度の同じ $\mathrm{C}_{3}$ 分 屑でも臟器により反応性を異にした. 5) $r$ glob. 抗体 との臟器 $\mathrm{C}$ 分屑の近似性は, 淋巴腺 $>$ 脾 $>$ 督 $>$ 肝の順で, また臟器では $\mathrm{C}_{3}>\mathrm{C}_{2}>\mathrm{C}_{1}$ の順序に交叉度が有り, Alb. 抗体には $\mathrm{C}_{1}>\mathrm{C}_{2}>\mathrm{C}_{3}$ の順序であった。 6) 肝電泳図 はglob. に属する易動度の举が多い. 眖水芒硝による $\mathrm{C}_{1}$, $\mathrm{C}_{2}, \mathrm{C}_{3}$ 分屑, 执よび Ethanol 分画による $\mathrm{C}_{1}, \mathrm{C}_{2}, \mathrm{C}_{3}$ 分 屑の電泳図を検討した. Alb. 嘱する易動度の峷は少か った. 牛水晶体蛋白の電泳図は 2 個の眀確な㸺が存し, その除は $\alpha, \beta$ Crystalline であることが分䇩の電泳図よ り証明された. 定量的沈降法では水晶体反応系は複合蛋 白系の形を示した．7）足蹠免疫法による家鬼の膝简淋 巴腺抗体量を定量的沈降法で測定し，淋巴組織抗体量は 淋巴液持よび血淸の抗体量より高いことを証眀した。 た溶解性蛋白の沈降 $\mathrm{N}$ 量は核扣よびミトコンドリア分 屑の沈降 $\mathrm{N}$ 量より多く, $\mathrm{Mw}>\mathrm{Nw}$ であり, また洗桜後 の淋巴球抽出液にも抗体が残存した．8）全身免疫法に 上る家鬼抗体の藏器抗体量を定量的沈降法で測定した結 果骨髓>脾>洗滌淋巴腺>肝>肺>腎の順が得られた。 9） r glob. 特よび抗体を作る淋巴腺执よび網內系に抗体 扣よび $r$ glob. 交叉蛋白が吸着, または含有されること が証明ざれたが，一方 Alb. を生虐する肝に Alb. が少 いことは, Alb. が肝で造られて後, 直ちに血中にでるか, または他の臟器も多少 Alb. 生産に関与するか何れかで 無いかと推定される. 緒方敉授の御指導に深謝の意を表 
する。

(1926)

交献

1) 高橋基之, 林靖, 本誌 1 卷 2 号 17 (1952) 等.

2) E.C. GJessing et al; J.B.C., 188, 155 (1951)

3) 岡崎卓一, 岡医誌, 498 号 (1931)

4) 岸岡精華, 岡医誌, 522 号 (1933) 531 号; 877 (1934)

5) 緒方正名, 本誌 1 尞 2 号, 21 (1952)

6) 緒方正名, 本誌 1 卷 3 号, 55 (1953)

7) 緒方正名, 本誌 2 卷 2 号 (1954)

8) A. Fujita, T. Kodama; Biochem. Z., 20, 232 (1931)

9) H. Masamune, K. Kodama ; J. Biochem., 14, 475 (1931-32)

10) C.J. Harrer, C.G. King ; J.B.C., 138, 111 (1941)

11) M.J. Kunitz; J. gen. phys., 30, 291 (1946-47)

12) W.C. Schneider; J.B.C., 176, 259 (1948)

13) G.R. Minot, Wp. Morphy; J.A.M.A., 87, 470
14) A.C. Wood \& E.L. Burky; J.A.M.A., 89, 102-110 (1927)

15) A.C. Wood et. al. ; Arch. Opth., 57, 464-466 (1928)

16) W·E. Ehrlich \& T.N. Harris; J. Exp. med., 76 (4), 335 (1942)

17) W.E. Ehrlich \& T.N. Harris \& E. Mertens; J. Exp. med., 83, 373 (1946)

18) T.N. Harris and Susanna Harris; J. axp. med., 90.

19) W.E. Ehrlich and W. Voigt; Beitr. path. Anat. ag. path., 93, 348 (1934)

20) Dougherty \& White; Endocrinology, 35 (1), 1 (1944)

21) S. Moeschlin und B. Demiral; Klin. Woch. schr., 30, 827 (1952)

22) T.N. Harris and Susanna Harris; J. immunol., 61 (1950)

（註）抗体含有量は $\mathrm{Mw}>\mathrm{Nw}$ の順であるが $\mathrm{I}^{131}$ ラ心゙ル抗原を用いて細胞內顆粒に含有される抗体と吸着反応を行っ た結果では $\mathrm{Mw}$ (Mitchondria) $>\mathrm{Pw}$ (Microsom) $>\mathrm{Nw}$ (Nucleus) の順になり, 前二者と $\mathrm{Nw}$ との差は大きい.

\section{近 時}

私共の研究室にあるチゼリウスの電気泳動裝置は誠に 不細工なものである.日立製の第 2 号とか第 3 号製品と かであるそうである．私共の処以外でも御使用になって おられる方は勿論あることと思われるが，現在のスマー トな製品に比べれば全くのバラック・セットと云えるで あろう. 何しろ水槽, レンズ系等が汽車の走るレールの 上に載ってるのである.始めてこの裝置が敎堂に届いた 時，相包の中に 7-8 尺もある恐しく重い箱があったが， 開けて見たらこのレールであった．何るレールを使わな くとも良いのにと思って聞いた処，丁度有り合せがあっ たのでこれに取りつけたという話であった。

始めてどうやらパターンが写るようになった時, 三三 の敉授にも見に来て戴くことにしたが，この時水槽の中 に氷を山に入れて冷したため，水槽のレンズが量ってぞ 万にも処置がない. 1 人が数秒見ている中に量ってしま 5。その度にレンズを拭くのであるが，操作している者 は全く汗みぞろになってしまった，その後もレンズの量 るのには手を暁いて，理髮店で使うドライャ一を使って みたり，また乾燥剤を使って見たり，苦心に苦心を重ね ねばならなかった。 またセルの破損にも悩まされ通しで あった．蓄電池から定電圧定電流裝置への改良，各分屑 の測定に重量法の探用等今日から見れば全くの常識的な ことが，その当時は非常な苦心を要した事柿であった。

\section{雜 感}

しかしこの不細工なバラック・セットにも捨て難い味 がある. 私共が現在夢中になっているこの裝置によって， アルブミンとグロブリンを別個に取り出すという仕事る このバラック・セットの御蕯である.この点から云えば 実験裝置というものは余りコンパクトにでき上ったもの が必ずしも最も価值のあるものとはいえないような気が する.

$$
* * * * *
$$

ハイルマイャーが来朝したりして，今後日本でも高電 圧濾紙電気泳動法が盛になると思われる，高電圧を用い゙

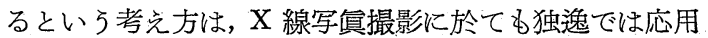
されて，すぐれた成果をあげている．しかし高電圧撮影 法は日本独自の蓄電放電式によるものと一利一害である ると考えられる。

$$
\text { * } * * *
$$

私は嘗つて行った分光分析に於ける断続孤光法の研究 から，滤紙電気泳動法にもこの裝置を応用したらと考兵 ている．時間と金があったら今年中に何とかして手をつ けたいと思うが，特志家の御協力を願う次第である.

\section{慶応義熟大学 五 味 二 郎}

